\title{
Embryonic Divergence of Oligodendrocyte and Astrocyte Lineages in Developing Rat Cerebrum
}

\author{
Steven M. LeVine ${ }^{a}$ and James E. Goldman \\ Departments of Pathology (Neuropathology) and Neuroscience, Albert Einstein College of Medicine, Bronx, \\ New York 10461
}

\begin{abstract}
Oligodendrocyte and astrocyte lineages were traced in rat forebrain sections using single- and double-label immunoperoxidase and indirect immunofluorescent techniques. Antibodies were directed against antigenic markers, the expressions of which overlapped in time: $G_{D 3}$ ganglioside in immature neuroectodermal cells; vimentin in radial glia; glial fibrillary acidic protein (GFAP) in astrocytes; and carbonic anhydrase (CA) and galactocerebroside (GC) in oligodendrocytes. A histochemical stain for iron was also used as a marker of oligodendrocytes. Small cells of the subventricular zone (SVZ) were stained with anti- $G_{D 3}$ but not with the other antibodies. By $16 \mathrm{~d}$ of gestation (E16), the SVZ generated large, round cells and thick, process-bearing cells that were $\mathrm{G}_{\mathrm{D} 3}{ }^{+} / \mathrm{CA}^{+} / \mathrm{iron}^{+}$. These cells then appeared in the cingulum and, with time, increased in numbers and extended thick processes as they filled the subcortical white matter. These cells eventually lost their reactivity to anti- $\mathrm{G}_{\mathrm{D} 3}$ but became $\mathbf{G C}+/ \mathbf{C A}^{+}$with processes extending to myelin sheaths. At E15 radial glia were stained with the anti-vimentin antibody but were negative for GFAP. At birth, only the vimentin ${ }^{+}$ radial glia midline between the 2 ventricles were GFAP ${ }^{+}$, but with time more vimentin ${ }^{+}$cells became GFAP ${ }^{+}$. By 7 d of postnatal age all the vimentin ${ }^{+}$cells were GFAP ${ }^{+}$and had converged predominately on the cingulum. With time these cells condensed and took on characteristic shapes of astrocytes. The embryonic separation of the oligodendrocyte and the astrocyte lineage is supported by four pieces of evidence: (1) $G_{D 3}+$ cells were double labeled with anti-CA, and then went on to become $\mathrm{GC}^{+}$; (2) vimentin ${ }^{+}$and GFAP+ cells were not also $\mathrm{G}_{\mathrm{D} 3}{ }^{+} ;$(3) ultrastructural localization of anti- $G_{D 3}$ was confined to cells with characteristics consistent with developing oligodendrocytes; and (4) the shapes of $\mathrm{G}_{\mathrm{D3}}{ }^{+}, \mathrm{CA}^{+}, \mathrm{GC}+$, or iron ${ }^{+}$cells did not resemble those of the vimentin ${ }^{+}$or GFAP ${ }^{+}$cells.
\end{abstract}

\footnotetext{
Received Apr. 1, 1987; revised Feb. 11, 1988; accepted Feb. 22, 1988.

Supported by NIH Grants NS17125 and NS07098. We thank Drs. William T. Norton and Wendy Cammer for discussions and comments on the manuscript, Ms. Yvonne Kress and Ms. Delilah Antonetty for expert assistance with ultrastructural studies, and Drs. Kenneth I loyd, Robert Yu, Victor Sapirstein, and Cedric Raine for antibodies.

Correspondence should be addressed to Dr. James E. Goldman at his present address: Department of Pathology, Columbia University Medical School and New York State Psychiatric Institute, Box 62, 722 West 168th St., New York, NY 10032

a Present address: Mental Retardation Research Center, University of California at Los Angeles, Los Angeles, CA 90024.

Copyright (C 1988 Society for Neuroscience $0270-6474 / 88 / 113992-15 \$ 02.00 / 0$
}

Among the many histogenetic events that occur during early CNS development is the generation of 2 glial classes, oligodendrocytes and astrocytes. There has been controversy over the origins of these cell types and the times at which they each originate. Early studies of gliogenesis suggested 2 very different views regarding lineages (for reviews, see Skoff, 1980; Wood and Bunge, 1984). One view held that oligodendrocytes and astrocytes arise from a common precursor cell. This common precursor cell was thought to be present at birth, and in some investigators' schemes it continued to be present well after birth. The other view held that the 2 cell lines diverge very early, sometime during gestational life. Included in this second view are cells in intermediate stages of differentiation which play a functional, and transient, role during the animal's development prior to the cell's final differentiated state. An example of this cell type is the radial glial cell, which in many parts of the CNS is present transiently during development and later becomes an astrocyte (Levitt and Rakic, 1980; Dahl et al., 1981; Bovolenta et al., 1984).

Distinguishing common precursor cells from cells that have just begun to differentiate can be difficult, because these recently divergent cells still have immature characteristics. Most of the early studies of gliogenesis have thus been limited in their identification of immature or developing glia since morphological criteria were the only means of their characterization. Much of the earlier morphological studies have examined either the optic nerve or the subcortical white matter, including corpus callosum. Early divergence of astrocytes and oligodendrocytes in optic nerve development was suggested by morphological studies (Vaughn, 1969; Skoff et al., 1976a, b). Recently, Raff and his colleagues have addcd furthcr conceptual and experimental details by tracing glial lineages in mouse optic nerve with antibody markers. They have presented evidence for 2 astrocyte lineages (Miller et al., 1985), one arising in embryonic life and the other arising postnatally from a progenitor cell that also gives rise to oligodendrocytes (Raff et al., 1984; Temple and Raff, 1985).

The patterns of gliogenesis in the subcortical white matter may be different from those in optic nerve, however. At early postnatal times, when oligodendrocytes are generated, there are substantial germinal centers, the subventricular zones (SVZ), lying adjacent to the lateral ventricles and just underneath the formative white matter. The optic nerve, in contrast, has little or no residual germinal plate at the time of oligodendrocyte genesis. Morphological and ${ }^{3} \mathrm{H}$-thymidine labeling studies have supported the view that both astrocytes and oligodendrocytes 
arise from cells of these germinal zones (Paterson et al., 1973; Sturrock, 1976; Imamoto et al., 1978). More recent studies, however, have shown that some astrocytes arise from radial glia, themselves established in midembryonic life (Schmechel and Rakic, 1979; Levitt and Rakic, 1980; Dahl et al., 1981; Bovolenta et al., 1984).

We have reexamined the development of oligodendrocytes and astrocytes in subcortical white matter and in other areas of the CNS using immunocytochemical techniques with antibodies that could specifically label different glial cell types or cells in different stages of development. We used antibodies against markers of immature neuroectodermal cells $\left(\mathrm{G}_{\mathrm{D} 3}\right.$ ganglioside), oligodendrocytes (carbonic anhydrase II and galactocerebroside), radial glia and astrocytes [vimentin and glial fibrillary acidic protein (GFAP)]. A histochemical stain for oligodendrocytes was also used (Francois et al., 1981; Hill and Switzer, 1984).

$\mathrm{G}_{\mathrm{D} 3}$ ganglioside is a prominent glycolipid species of the immature but not the mature CNS. A monoclonal antibody against $\mathrm{G}_{\mathrm{D} 3}$ ganglioside, R24 (Pukel et al., 1982), binds to SVZ cells and cells of the external germinative layer of the cerebellum in rat CNS (Goldman et al., 1984) and to cells of the neural tube in chicken (Rosner et al., 1985). Immature neurons in the rat CNS seem to lose antibody binding very early in differentiation. Thus, granule cell precursors migrating from the external germinative layer no longer bind R24 (Goldman et al., 1984), and we have not seen neuronal populations in rat brain that bind the antibody, under the conditions we have employed (see Results). In our previous study, we noted positive cells in formative white matter (Goldman et al., 1984). The evidence presented in this report suggests that these are glial. Double-labeling experiments using oligodendrocyte and astrocyte markers were then used in conjunction with R24 to identify the developmental course of the SVZ germinal cells. This strategy is possible if cells retain $G_{D 3}$ expression while they acquire characteristics of mature glia. By using a series of markers, the expressions of which overlapped temporally, we hoped to create a developmental sequence spanning the entire developmental course of glial cells.

Carbonic anhydrase II is abundant in oligodendrocytes of CNS white matter. In most studies it has appeared to be a specific marker for oligodendrocytes (Spicer et al., 1979; Ghandour et al., 1980; Langley et al., 1980; Kumpulainen and $\mathrm{Ny}-$ strom, 1981; Kumpulainen et al., 1983; Cammer, 1984; Cammer et al., 1985), although small amounts might be present in astrocytes of the gray matter. Antibodies to galactocerebroside have been used to label oligodendrocytes in vivo and in vitro (Raff et al., 1979; Zalc et al., 1981).

Radial glia in human and monkey CNS express the intermediate filament protein GFAP (Choi and Lapham, 1978; Levitt and Rakic, 1980). In rodent CNS, however, GFAP is not initially expressed by radial glia; rather, vimentin is first present, with GFAP expression arising just before or after birth (Dahl et al., 1981; Schnitzer et al., 1981; Bovolenta et al., 1984). Thus, we used antibodies against vimentin and GFAP to trace the fate of radial glia in the rat. We were also able to use these antibodies in double-labeling experiments with the anti- $G_{D 3}$ antibody and other markers.

In this report we present evidence suggesting an embryonic divergence of oligodendrocyte and astrocyte cell lineages. Further details of the patterns of oligodendrocyte differentiation and transitions in cell morphology are presented elsewhere (LeVine and Goldman, 1988a, b).

\section{Materials and Methods}

Tissue preparation. Timed pregnant Wistar rats were purchased from Charles River Laboratory (Wilmington, MA). For prenatal studies the mother was anesthetized, and the uterus was removed surgically and placed in ice-cold PBS. Fetuses of $16 \mathrm{~d}$ gestational age (E16), E18, and E20 were perfused through their left ventricles with $2.5 \%$ glutaraldehyde (EM grade, Polyscience, Inc., PA) in PBS. The brains were removed and placed in $2.5 \%$ glutaraldehyde in PBS for $3 \mathrm{hr}$ at $4^{\circ} \mathrm{C}$ and then transferred to PBS overnight at $4^{\circ} \mathrm{C}$. E1 5 fetuses were decapitated and the head was placed in $2.5 \%$ glutaraldehyde overnight at $4^{\circ} \mathrm{C}$.

For postnatal studies, litter sizes were reduced to 8 pups per mother to insure uniform nutrition and animals $0,1(\mathrm{P} 1), 2,3,4,7,8,10,11$, $14,16,17,18,21,28$, and $45 \mathrm{~d}$ of age were processed as were the E1620 fetuses.

Fifty- to $100-\mu \mathrm{m}$-thick coronal sections between the most anterior region of the corpus callosum to the most anterior region of the hippocampus were cut with a Vibratome. The thicker sections were cut from the younger animals.

Antibodies. The properties and specificity of the mouse monoclonal antibody AbR24, which binds to $G_{D 3}$ ganglioside (Pukel et al., 1982; Kasai et al., 1984; Goldman et al., 1984), the rabbit anti-rat CA (Cammer et al., 1985), and the rabbit anti-GC (Norton et al., 1983) have been described elsewhere. The mouse monoclonal A2B5 has been reported as specific to ganglioside $\mathrm{G}_{\mathrm{QIc}}$ in one report (Kasai and $\mathrm{Yu}, 1983$ ) but less specific in another (Fredman et al., 1984). The mouse monoclonal antibody to vimentin was purchased from Boehringer Mannheim Biochemicals (IN). We confirmed its specificity and lack of cross-reactivity with GFAP by Western blots of rat brain proteins (not shown). Rabbit anti-human GFAP antiserum was raised and characterized by Chiu and Goldman (1984).

Peroxidase-antiperoxidase single stains. Vibratome sections were incubated with the following solutions at room temperature: $3 \% \mathrm{H}_{2} \mathrm{O}_{2}$ in PBS, 5 min; PBS, until bubbles were no longer visible; $\mathrm{NaBH}_{4}, 10 \mathrm{mg}$ / $\mathrm{ml}$ in PBS, $30 \mathrm{~min}$; PBS, until bubbles were no longer visible; $10 \%$ rabbit serum (RS) (used with mouse monoclonal antibodies) or $10 \%$ swine serum (SS; used with rabbit antisera) in PBS, $15 \mathrm{~min}$; mouse monoclonal anti- $G_{D_{3}}$ in ascites fluid, $1: 500$ in $1 \% \mathrm{RS}$, mouse monoclonal anti-vimentin 1:50 and $1: 100$ or A2B5 1:1500 in 1\% RS, rabbit antihuman GFAP antiserum, $1: 100$ and 1:250 in 1\% SS, or rabbit anti-rat CA 1:200 in 1\% SS, 45 min; PBS $\times 2,5$ min each; rabbit anti-mouse $\mathrm{IgG}$ antiserum (Sternberger-Meyer Immunohistochemicals, Inc., Jarrettsville, MD) diluted 1:20 in PBS (used with mouse monoclonals) or swine anti-rabbit Ig (Accurate Chemicals, Westbury, NY) 1:20 in PBS (used with the rabbit antisera), $30 \mathrm{~min}$; PBS $\times 2,5 \mathrm{~min}$; peroxidaseantiperoxidase complex, mouse monoclonal origin (Sternberger-Meyer) $1: 50$ in 1\% RS (used with the mouse monoclonals) or peroxidase-antiperoxidase complex, rabbit origin (Accurate Chemicals) $1: 50$ in 1\% $\mathrm{SS}$ (used with the rabbit antisera), $30 \mathrm{~min}$; PBS $\times 2,5 \mathrm{~min} ; 1.5 \mathrm{mg} \mathrm{3,3}$ diaminobenzidine (DAB) (Sigma Chemical Company, St. Louis); $3 \mathrm{ml}$ $0.01 \mathrm{~m}$ Tris (Sigma), pH 7.6: $1 \mu 130 \% \mathrm{H}_{2} \mathrm{O}_{2}$ added immediately before use, $8 \mathrm{~min}$ in the dark; $\mathrm{PBS} \times 2,5 \mathrm{~min}$. At this point some of the sections from $E 18, P 4$, and $P 10$ animals stained with anti- $G_{D 3}$ were processed for electron microscopy (see below), while the other sections were either further processed for double-labeling experiments or mounted on a slide dipped in gelatin, dehydrated, coverslipped with Permount (Fisher, Fair Lawn, NJ) and viewed with an Olympus BH-2 photomicroscope equipped with Nomarski optics. All antigens appeared stable in glutaraldehyde and to the various treatments performed on the tissues.

Double-staining with anti-CA/anti- $G_{D 3}$, anti-vimentin/anti- $G_{D 3}$, and anti-GFAP/anti-G $G_{D 3}$ antibodies. PAP stains were performed as described above for anti-CA, anti-vimentin, and anti-GFAP antibodies. After the last PBS washes from the first staining, the sections were incubated in the following solutions: diluent solution $(10 \%$ lamb serum, $10 \%$ fetal calf serum in PBS), 15 min; mouse monoclonal anti- $G_{\nu 3}$ in ascites fluid, $1: 300$ dilution in diluent, $\mathbf{4 0}$ min; $P B S \times 2,5$ min each; rhodamine $(\mathrm{Rh})-$ conjugated goat anti-mouse Ig (heavy and light chain specific; Cooper, Cochranville, PA), 1:50 in PBS, 30 min; PBS $\times 2,5$ min each; mounted in Gelvatol on a slide. Slides were viewed and photographed with an Olympus BH photomicroscope equipped with epifluorescent optics and filters for rhodamine and fluorescein.

Experiments were also performed using anti- $G_{D 3}$ in the PAP/DAB procedure with anti-vimentin or anti-GFAP visualized using indirect immunofluorescence. In these experiments, the anti- $G_{D 3}$ was used as described for peroxidase-antiperoxidase single stains. After the last PBS 

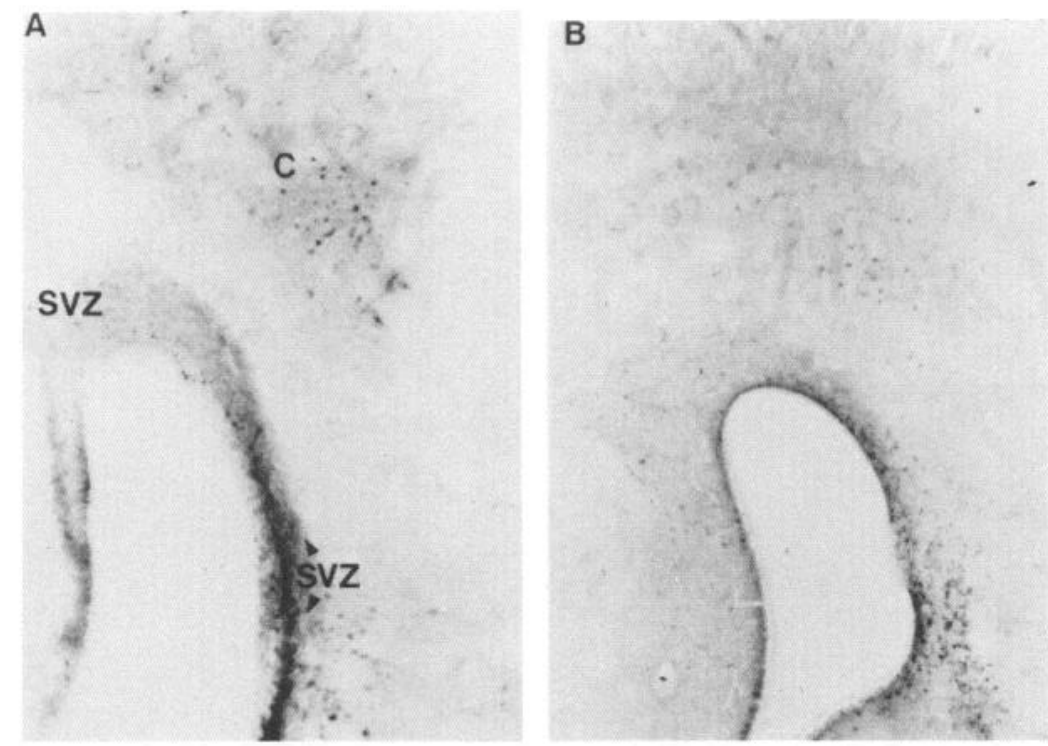

C

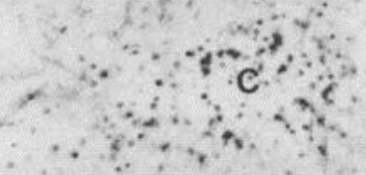

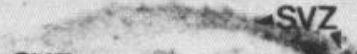
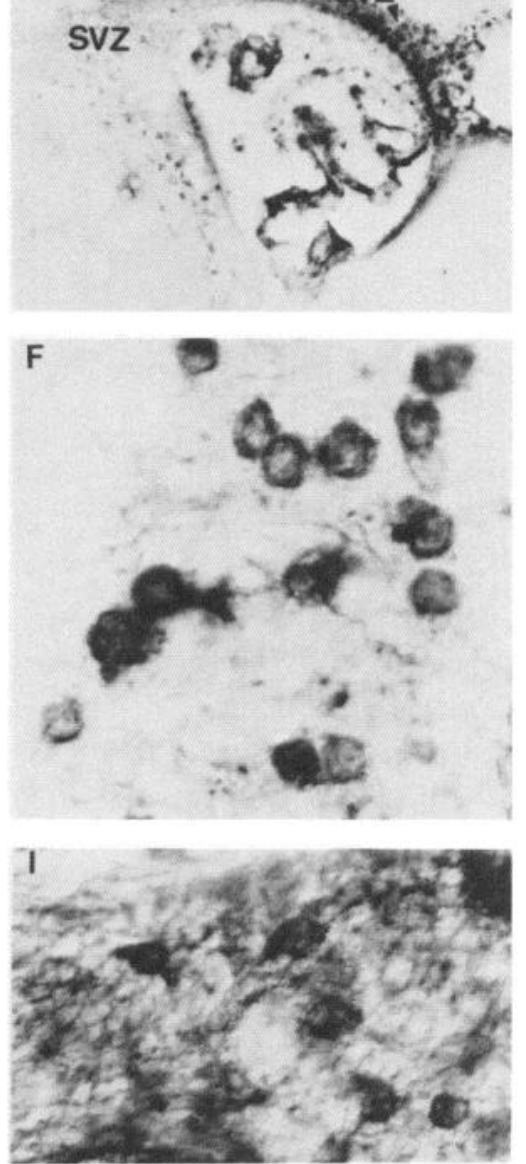

D
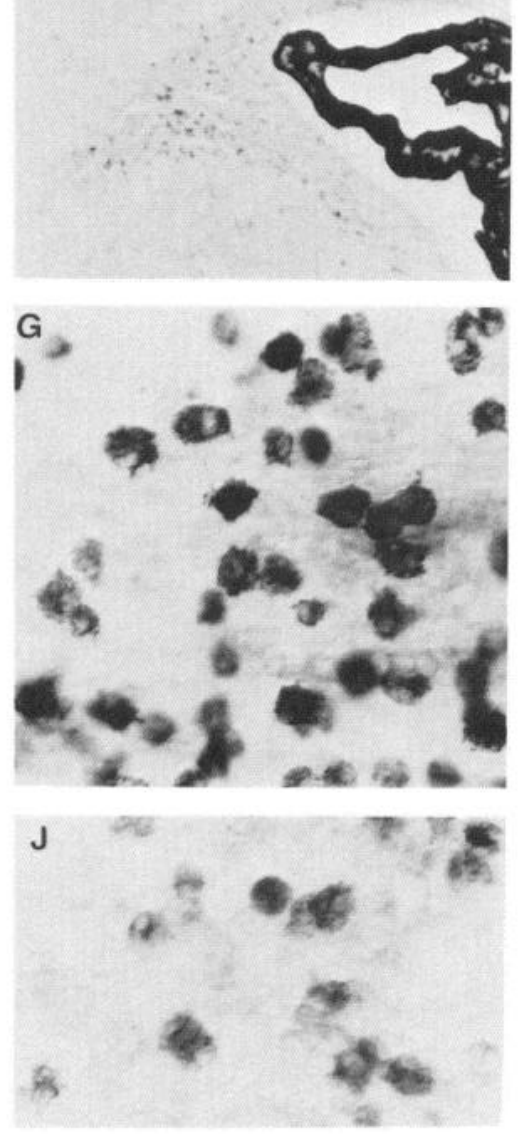

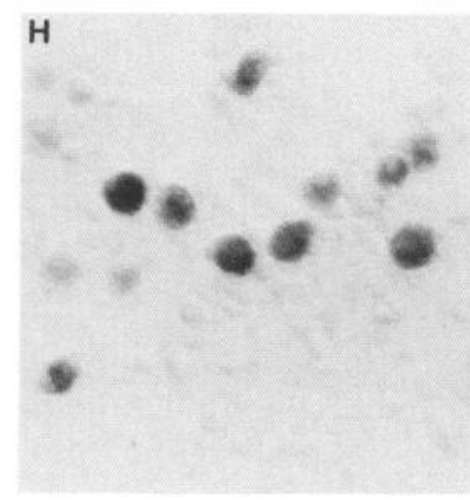

E
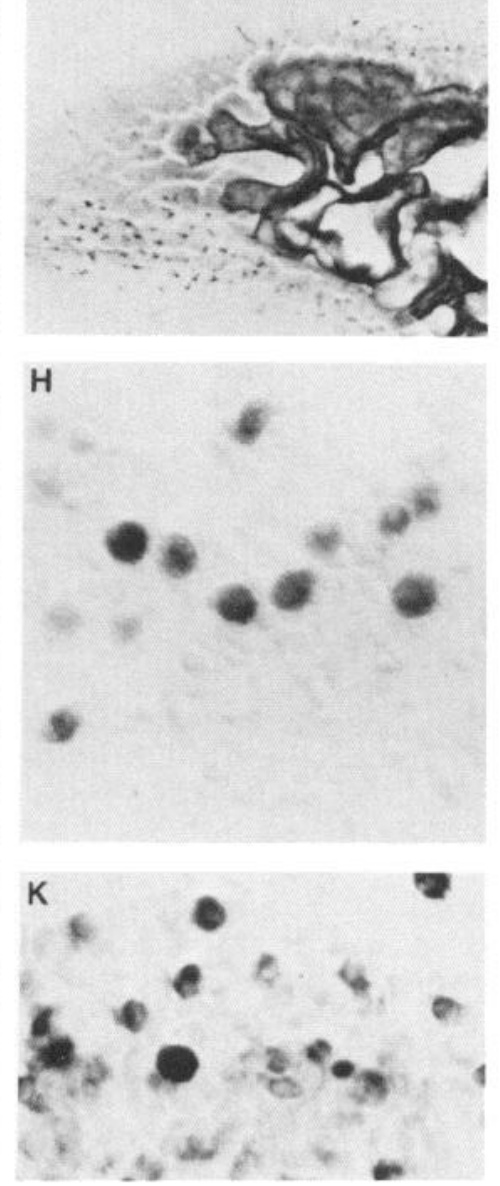
washes from the first staining, the sections were incubated in the following solutions: diluent, $15 \mathrm{~min}$; 1:40 dilution mouse monoclonal antivimentin or 1:50 dilution of rabbit anti-human GFAP in diluent, 40 min; PBS $\times 2,5$ min each; Rh-goat-anti-mouse Ig, 1:50 in PBS or fluorescein isothiocyanate (FITC)-conjugated goat-anti-rabbit Ig (Cappell) 1:50 in PBS, $30 \mathrm{~min}$; PBS $\times 2,5$ min each; mounted in Gelvatol on a slide. Identical results were seen whether the anti- $\mathrm{G}_{\mathrm{D} 3}$ or an intermediate filament antibody was used first.

We attempted to stain sections with anti-GFAP and anti-vimentin antibodies by the above method. We observed, however, that the antibody used first (anti-vimentin) with the PAP procedure blocked the second antiserum (anti-GFAP) from binding to GFAP in animals where single stains showed both vimentin and GFAP to be present. The probable reason for this technical difficulty is that vimentin and GFAP form heteropolymers (Sharp et al., 1982) and the DAB reaction product deposition on filaments may block further antibody binding. By changing the procedure from the PAP/immunofluorescence method to a doublelabeled immunofluorescence procedure (see below), we found doublelabeled cells readily. In a PAP/immunofluorescence experiment using anti-vimentin or anti-GFAP together with anti-CA we observed no double labeling of the same cells. A study by Ghandour et al. (1979) used a method very similar to the PAP/immunofluorescence procedure described here to determine if CA and GFAP are within the same cell. Since CA has been shown to have a diffuse cytoplasmic localization (Ghandour et al., 1980; Langley et al., 1980), the reaction product might block further cytoplasmic antigens from reacting with antibodies, possibly giving rise to a false-negative result. Because of this consideration we do not feel confident that this method is the correct choice for the demonstration of CA and GFAP or vimentin within the same section. Under certain conditions the DAB/fluorescence method has been used successfully to demonstrate 2 cytoplasmic antigens within the same cell, however. A study by Lechago et al. (1979) demonstrated pepsinogen I and pepsinogen II within the same cell. The intensity of the fluorescence observed, however, was inversely proportional to that of the peroxidase reaction. Therefore, some "tailoring" of the peroxidase reaction became necessary so that it did not interfere with the fluorescence. This problem was not observed when the antigen visualized with the peroxidase reaction was cytoplasmic and the antigen visualized with the immunofluorescence reaction was membranous, such as $G_{D 3}$.

Single staining with anti-GC. Tissue sections were incubated in the following solutions: $10 \mathrm{mg} / \mathrm{ml} \mathrm{NaBH}{ }_{4}, 30 \mathrm{~min}$; PBS, until bubbles were no longer observed; diluent solution, $15 \mathrm{~min}$; anti-GC antiserum, 1:100 dilution in diluent $1 \mathrm{hr}$; PBS $\times 2,5 \mathrm{~min}$ each; FITC-goat-anti-rabbit Ig (Cappell) 1:50 in PBS, $1 \mathrm{hr}$; PBS $\times 2,5$ min each. The sections were then postfixed in $10 \%$ acetic acid $/ 90 \% \mathrm{EtOH}$, washed in PBS, and mounted in Gelvatol on a slide.

Double staining with anti-CA/anti-GC. A PAP stain was performed as described above for anti-CA. Following the last PBS washes from the anti-CA staining, the sections were treated identically to the single stain for anti-GC with the elimination of the $\mathrm{NaBH}_{4}$ and acetic acid/ EtOH incubation. The sections were then mounted in Gelvatol on a slide. Note that these are both rabbit antisera. Controls omitting the anti-GC antibody or substituting normal rabbit serum for the anti-GC antibody did not reveal any binding of the second primary antibody to the swine-anti-rabbit bridge or binding of the FITC-goat-anti-rabbit Ig to the anti-CA or rabbit PAP antibodies. Therefore, the DAB reaction product successfully blocked the antibodies used in the PAP staining, a phenomenon previously described by Sternberger and Joseph (1979). We observed a cytoplasmic staining with the anti-CA and a cell surface staining with the anti-GC (see Results).

Double staining with anti-GFAP/anti-vimentin. Vibratome sections were incubated in the following solutions: $10 \mathrm{mg} / \mathrm{ml} \mathrm{NaBH}_{4}, 30 \mathrm{~min}$; PBS until bubbles were no longer visible; diluent, $15 \mathrm{~min}$; a mixture of anti-GFAP 1:50 and anti-vimentin 1:40 diluted in diluent, $45 \mathrm{~min}$; PBS $\times 2,5$ min each; a mixture of FITC-goat-anti-rabbit Ig (Cappell) 1:50 and $\mathrm{Rh}$ goat anti-mouse Ig (Cappell) 1:50 in PBS, $30 \mathrm{~min}$; PBS $\times 2,5$ min each; and mounted in Gelvatol on a slide.
Tissue processing for electron microscopy. Vibratome sections from $\mathrm{E} 18, \mathrm{P} 4$, and $\mathrm{P} 10$ animals, previously stained with anti- $\mathrm{G}_{\mathrm{D} 3}$ using the PAP technique, were postfixed in $0.5 \%$ glutaraldehyde in PBS overnight Sections were then exposed to $1 \% \mathrm{OsO}_{4}$ for $1 \mathrm{hr}$ and embedded in Epon between 2 plastic coverslips. The sections were examined with a light microscope and the areas of interest cut out and reembedded in Beem capsules. Thin sections were cut, mounted on copper grids, and stained with $1 \%$ uranyl acetate for $10 \mathrm{~min}$ and lead citrate for $2 \mathrm{~min}$. The sections were examined in a Siemens 101 electron microscope.

Histochemical stain for iron. Tissue sections were treated with a freshly prepared $1: 1$ mixture of $0.25 \mathrm{M} \mathrm{HCl}$ and $2 \%$ potassium ferrocyanide (Fisher) for $30 \mathrm{~min}$. This was exchanged for a new mixture of the $\mathrm{HCl} /$ potassium ferrocyanide solution and allowed to incubate for an additional $30 \mathrm{~min}$. The sections were washed in PBS and then treated with

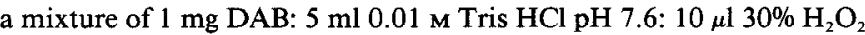
for $10 \mathrm{~min}$. They were then dipped in a gelatin solution, allowed to air dry, dehydrated, and mounted with Permount.

Controls. Peroxidase-antipcroxidasc staining tcchniques using DAB as a substrate have been shown to block further antibody binding effectively (Sternberger and Joseph, 1979). We controlled the PAP-DAB/ immunofluorescence experiments by omitting the second primary antibodies or replacing them with mouse monoclonal antibodies agains antigens that would not be detected, such as keratin, or with normal rabbit serum. No immunofluorescence was observed under these control conditions for both the mouse and rabbit antibodies employed in the immunofluorescence staining. An internal control was present for the immunofluorescence staining in the anti- $\mathrm{G}_{\mathrm{D} 3}$ with anti-GFAP or antivimentin $\mathrm{PAP}-\mathrm{DAB} / \mathrm{imm}$ unofluorescence experiments since no double labeling of the same cells was observed (see Results). An internal control for anti-CA (PAP-DAB)/anti-GC (immunofluorescence) was present in that $\mathrm{CA}^{+}$cells in the cingulum were not double labeled with anti-GC, whilc $\mathrm{CA}^{+}$cells further laterally in the same section werc double labeled.

The double-labeling immunofluorescence experiments were controlled by omitting one of the primary antibodies or replacing the primary antibody with normal rabbit serum for anti-GFAP or anti-keratin for anti-vimentin. No immunofluorescence other than that of the uncontrolled antibody was observed.

We controlled for the iron histochemical staining by omitting the potassium ferrocyanide/ $\mathrm{HCl}$. No staining other than red blood cells was observed.

\section{Results}

\section{Oligodendrocyte lineage}

The anti- $\mathrm{G}_{\mathrm{D} 3}$ antibody used in this study has been previously shown to stain cells of the SVZ by an immunofluorescence method (Goldman et al., 1984). We used anti- $\mathrm{G}_{\mathrm{D} 3}$ in single- and double-labeling experiments together with antibodies against astrocyte and oligodendrocyte markers, and a histochemical stain for oligodendrocytes, at various times to trace the developmental fate of the SVZ cells. Single-labeling experiments were also performed with the various antibodies against glial markers, and results were compared to those with the anti- $\mathrm{G}_{\mathrm{D} 3}$ antibody.

Cells of the SVZ were small and tightly packed. In contrast to the cells of the overlying cortex, SVZ cclls bound the anti$\mathrm{G}_{\mathrm{D} 3}$ antibody, confirming our previous report of $\mathrm{G}_{\mathrm{D} 3}{ }^{+} \mathrm{SVZ}$ cells (Goldman et al., 1984), but at an earlier age and with a different method. Beginning at E16 and continuing through the first week and a half of postnatal life, there appeared in the SVZ a population of cells that could be readily distinguished from the small $\mathrm{G}_{\mathrm{D} 3}+\mathrm{SVZ}$ cells. These were large and round or large with short processes. They continued to bind the anti- $\mathrm{G}_{\mathrm{D} 3}$ antibody but additionally bound the anti-CA antiserum. Identical large, round

Figure 1. Anti- $\mathrm{G}_{\mathrm{D} 3}$ staining (PAP) is observed in large cells within the cingulum $(C)$ and in small, as well as large, cells in the subventricular zone $(S V Z)$ at E18 $(A)$ and $\mathrm{P} 1(C)$. $\times 40$. Anti-CA staining (PAP) at E18 $(B)$ and $\mathrm{P} 1(D)$ is observed in large cells within the cingulum, but, unlike anti$\mathrm{G}_{\mathrm{D} 3}$, anti-CA is observed only in large cells in the SVZ. $\times 40 . E$, Iron staining pattern is similar to that with anti-CA (P4). $\times 40$. Large, round cells in the cingulum are stained with $(F)$ anti- $\mathrm{G}_{\mathrm{D} 3}(\mathrm{P} 1),(G)$ anti-CA $(\mathrm{Pl})$, and $(H)$ iron $(\mathrm{P} 4) . \times 396 . I$, Within the SVZ large $\mathrm{G}_{\mathrm{D} 3}{ }^{+}$cells are admixed with smaller $\mathrm{G}_{\mathrm{D} 3}{ }^{+}$cells. $\times 396$. Anti-CA $(J)$ and Prussian blue $(\mathrm{DAB})(K)$ stains the large cells, but not small cells, in the SVZ. $\times 396$. 

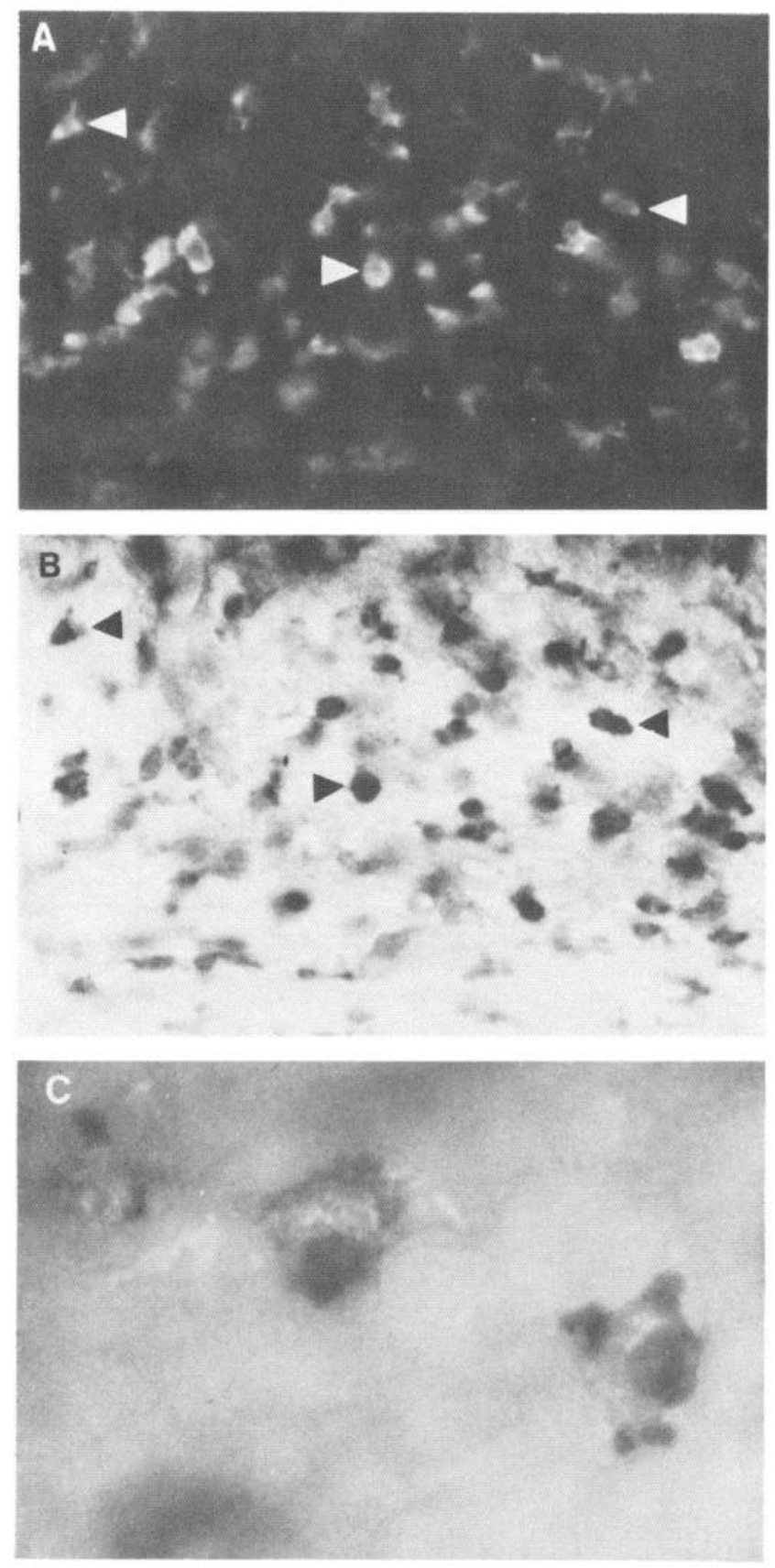

Figure 2. A double-labeled section for $(A)$ anti- $\mathrm{G}_{\mathrm{D} 3}(\mathrm{Rh})$ and $(B)$ antiCA (PAP) at P11, showing numerous double-labeled cells (some indicated by arrowheads). $\times 198$. C, Cells in the cingulum stained with both anti-G $\mathrm{G}_{\mathrm{D} 3}(\mathrm{Rh})$ and anti-CA (PAP) (double exposure), E18. $\times 1155$.

cells that were $\mathrm{G}_{\mathrm{D} 3}{ }^{+} / \mathrm{CA}^{+}$were also observed within the cingulum, the expanse of subcortical white matter just above the bulk of the SVZ, and in the white matter that lay between the cingulum and SVZ (Figs. 1, 2).

The $\mathrm{G}_{\mathrm{D} 3}{ }^{+} / \mathrm{CA}^{+}$cells maintained a high double-labeling efficiency up to P4 in the SVZ and cingulum. Thereafter, the doublelabeling efficiency decreased, with more $\mathrm{CA}^{+}$cells than $\mathrm{G}_{\mathrm{D}_{3}}{ }^{+}$ cells observed. At no time did the anti-CA antiserum stain the small $\mathrm{G}_{\mathrm{D} 3}{ }^{+}$cells in the SVZ (Fig. 1).

From E18 through the first week of postnatal life, the large, round $\mathrm{G}_{\mathrm{D} 3}{ }^{+} / \mathrm{CA}^{+}$cells increased in number and density within the cingulum. During this period, such cells appeared further and further laterally in the subcortical white matter and medially in the corpus callosum. The cells situated further from the SVZ displayed a process-bearing morphology (Fig. 3). $\mathrm{G}_{\mathrm{D} 3}+/ \mathrm{CA}^{+}$cells from the cingulum also appeared in the overlying cortex, first in zones close to the cingulum, and then more widely spread. Although our observations are of static images, we suggest that the various transitions in time, space, and form represent migration into the lateral white matter and corpus callosum for several reasons: (1) at early times, large round $\mathrm{G}_{\mathrm{D} 3}+/ \mathrm{CA}^{+}$cells resided within the cingulum and were not found in the lateral white matter or corpus callosum; (2) with time, process-bearing cells that were $\mathrm{G}_{\mathrm{D} 3}{ }^{+} / \mathrm{CA}^{+}$began to appear in the white matter lateral and medial to the cingulum; (3) these cells showed a spectrum of shapes, from ellipsoidal cells that lay closer to the cingulum to cells with more processes that resided more laterally; and (4) these cells continued to increase in number and populate more of the lateral white matter with time. The details of these transitions and a consideration of cells in hemispheric gray matter and in cerebellum are discussed at greater length elsewhere (LeVine and Goldman, 1988a, b).

A histochemical stain for iron reacted with cells that appeared identical to $\mathrm{G}_{\mathrm{D} 3}+/ \mathrm{CA}+$ cells (Fig. 1). No cells with the morphologies of $\mathrm{GFAP}^{+}$or vimentin ${ }^{+}$cells were iron ${ }^{+}$.

A further indication that the $\mathrm{G}_{\mathrm{D} 3}+/ \mathrm{CA}^{+}$cells were developing along an oligodendrocytic line was provided by staining with an anti-GC antiserum. Anti-GC antiserum stained cells in white matter with thin processes and stained myelin sheaths at P7 and P10 (Fig. $4 A$ ). $\mathrm{GC}^{+}$cells were also observed at P5, but only a few were present at this age. Many of the $\mathrm{GC}^{+}$cells bore a thin process that appeared to extend to a myelinated axon. By P10 the $\mathrm{GC}^{+}$cells and myelin sheaths were present in greater numbers and density than at P7. The $\mathrm{GC}^{+}$cells were double-labeled with anti-CA antiserum (Fig. 4, B, C). The number of $\mathrm{GC}^{+}$cells in single-staining experiments exceeded the number of $\mathrm{GC}^{+}$cells observed in double-labeling experiments with anti-CA, however. The smaller numbers of $\mathrm{GC}^{+}$cells in the double-labeling experiments may be a result of some interference by the DAB reaction product from the $\mathrm{CA}$ stain. A transition from soluble to membrane-bound $\mathrm{CA}$ has been described in developing rat forebrain (Sapirstein, 1983). At birth, 90\% of CA is soluble, but between $\mathrm{P} 0$ and P10 the membrane-bound CA slowly increases to become greater than or equal to the soluble form by P10 (Sapirstein, 1983). CA has also been localized to myelin sheaths and interfascicular oligodendrocytes (Cammer et al., 1976; Yandrasitz et al., 1976; Sapirstein et al., 1978; Spicer et al., 1979; Kumpulainein and Nystrom, 1981; Kumpulainein and Korhonen, 1982). Thus, the membrane-bound form of CA could account for the anti-CA immunohistochemistry interfering with binding of the anti-GC antiserum, which binds to the oligodendrocyte membrane.

At no age examined did the small SVZ cells $\left(\mathrm{G}_{\mathrm{D}_{3}}{ }^{+}\right)$or any of the $\mathrm{G}_{\mathrm{D}^{+}}{ }^{+}, \mathrm{CA}^{+}$, or $\mathrm{GC}^{+}$cells show any morphological similarities to the cells stained with the anti-GFAP antiserum or the anti-vimentin antibody (compare Figs. 1, 2, and 3 with Figs. 7 and 8). Furthermore, double-labeling experiments using anti$\mathrm{G}_{\mathrm{D} 3}$ with anti-GFAP or anti-vimentin failed to show a concordance of staining (Fig. 5). We also performed double-labeling experiments using anti-GFAP, visualized using a PAP method with 4-chloro-1-naphthol together with anti- $\mathrm{G}_{\mathrm{D}_{3}}$ stained with PAP/DAB. No double labeling of cells was observed using this alternative method (data not shown). 


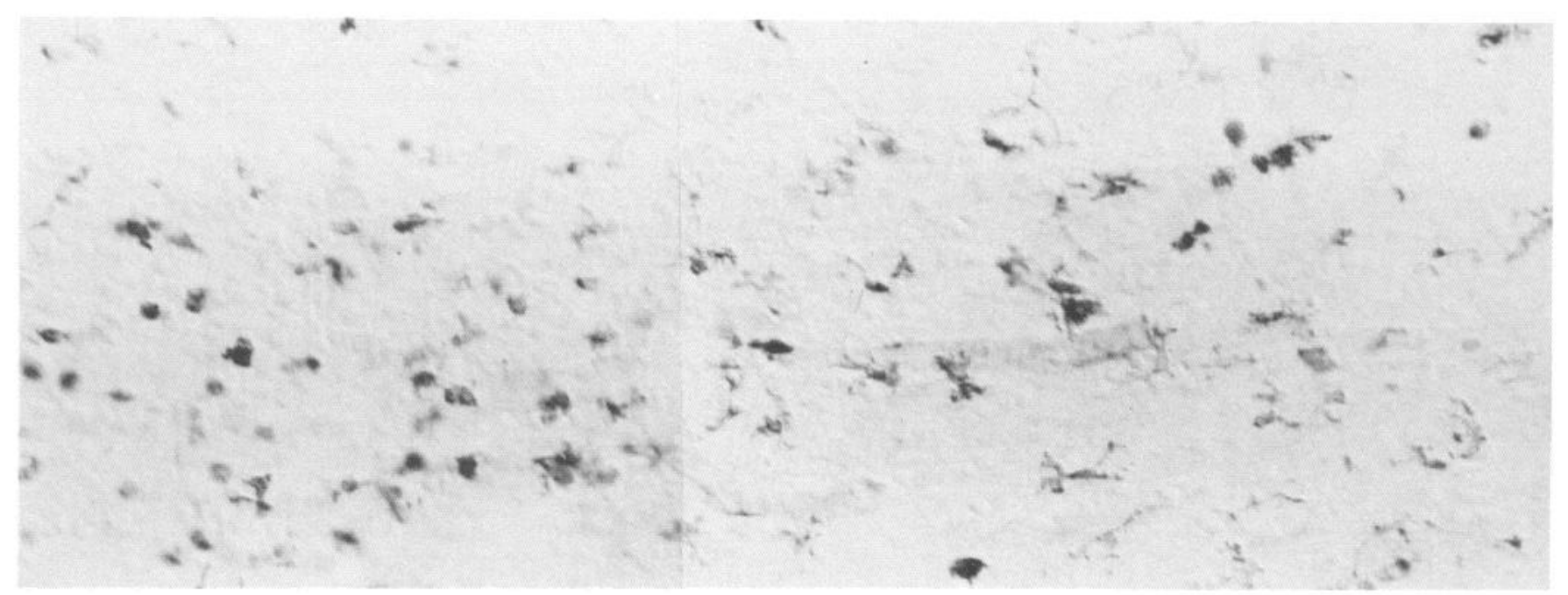

Figure 3. Anti-CA staining showing transitions in cell shapes at P4. Large, round cells are observed at the periphery of the cingulum (left); cells with more processes are observed in more lateral white matter (right), and intermediate forms are observed in between (center). $\times 277$.

The observations noted above suggest that these markers define cells differentiating along oligodendrocytic lines. To provide further evidence for oligodendrocyte development of the $\mathrm{G}_{\mathrm{D} 3}{ }^{+}$ cells, immunocytochemical labeling was performed at the ultrastructural level (Fig. 6). In E18, P4, and P10 animals, the labeled cells displayed characteristics consistent with immature glia and developing oligodendrocytes, based on the presence of varying combinations of the following features: a large nuclear to cytoplasmic ratio, nuclear invagination in the larger cells, a granular nuclear appearance with peripheral chromatin clumping, Golgi apparatus, the presence of free ribosomes and of microtubules in cell processes, and the absence of intermediate filaments and of glycogen granules. The P10 animals displayed more labeled cells with processes, a diminished nuclear to cytoplasmic ratio, and more microtubules than did the P4 animals. We have examined large numbers of $\mathrm{G}_{\mathrm{D} 3}{ }^{+}$cells in developing white matter from animals aged E18, P4, and P10 (LeVine and Goldman, 1988b) and have provided here 3 representative examples of cells in different stages.

Since the monoclonal antibody A2B5 stains precursor cells that can differentiate into oligodendrocytes or astrocytes in the optic nerve (Miller et al., 1985), we thought it would be interesting to examine its patterns of reactivity in forebrain sections. At late embryonic stages, A2B5 staining was observed in the small SVZ cells, in large, round cells in the SVZ and white matter (Fig. 7), in neuronal cell bodies and in axons in the white matter (not shown). The large, round cells were similar to the large, round $\mathrm{G}_{\mathrm{D} 3}{ }^{+} / \mathrm{CA}^{+}$cells and were present in similar locations. By birth, however, the neuronal and axonal staining was so intense that it became difficult to identify individual cells in developing white matter.

\section{Astrocyte lineage}

In the rodent CNS, radial glia express vimentin. We used an antibody against vimentin together with antibodies against markers of oligodendrocytes and astrocytes to trace the fate of the vimentin ${ }^{+}$radial glia. At E15, clustered, thick vimentin ${ }^{+}$ radial glia extended from the ventricular surface to the pial surface (Fig. 8A). Anti-GFAP antiserum did not show any staining at this age. As the brain grew in the next several days, the radial glial processes became thinner and more elongated, traversing the now much greater width of the cortex. By E18 a few vimentin $^{+}$radial glia could be seen with their tips detached from the pial surface. At P0 several vimentin ${ }^{+}$processes lost their pial attachments (Fig. $8 B$ ). At $\mathrm{P} 4$ many vimentin ${ }^{+}$radial glia were converging on the cingulum, while others resided in the gray matter. At P8 a tangled mesh of fibers twisted in every direction was seen within the cingulum (Fig. 8C). At P16 no vimentin ${ }^{+}$radial processes were observed. The vimentin ${ }^{+}$cells have condensed, taking on the characteristic shapes of astrocytes (Fig. 8D).

At E18 both the anti-GFAP and anti-vimentin antibodies stained delicate, radially oriented processes that lay medially between the 2 ventricles and between the ventricles and the base of the central commissure (Fig. 9, $A, B$ ). Those in the cingulum were only vimentin ${ }^{+}$, however (Fig. $9, C, D$ ). The number of $\mathrm{GFAP}^{+}$processes increased with age, but the fully elongated vimentin $^{+}$radial glial processes originating from the superior surface of the ventricle only showed a faint GFAP staining. The anti-GFAP antiserum readily stained the vimentin ${ }^{+}$radial glial processes once they had converged on the cingulum by P4-P7 (Fig. 9, E, F). Double-label experiments showed that GFAP was first detectable only in processes that were also vimentin ${ }^{+}$. The percentage of vimentin ${ }^{+}$processes that were double labeled with the anti-GFAP antiserum increased with age. It was at P7, with most of the vimentin ${ }^{+}$processes converged on the cingulum, that the percentage of vimentin ${ }^{+}$cells that were also GFAP ${ }^{+}$ approached $100 \%$. Between P8 and P10 the tangled mesh of $\mathrm{GFAP}^{+} /$vimentin $^{+}$processes within the cingulum condensed and began to take on characteristic shapes of astrocytes.

Neither the anti-vimentin antibody nor the GFAP antiserum stained small SVZ germinal plate cells. This was also true at higher concentrations of anti-vimentin (1:50) and anti-GFAP (1:100) in PAP single stains. Anti-vimentin and anti-GFAP also did not stain the large, round $\mathrm{G}_{\mathrm{D} 3}{ }^{+} / \mathrm{CA}^{+}$cells in the cingulum or any other cells with the morphology of those stained with the anti- $\mathrm{G}_{\mathrm{D} 3}$ antibody or the anti-CA antiserum within the subcortical white matter or germinal plate. Double-labeling experiments using anti- $\mathrm{G}_{\mathrm{D} 3}$ with anti-vimentin and anti-GFAP failed to show a concordance of staining in the same cell (Fig. 5). The 

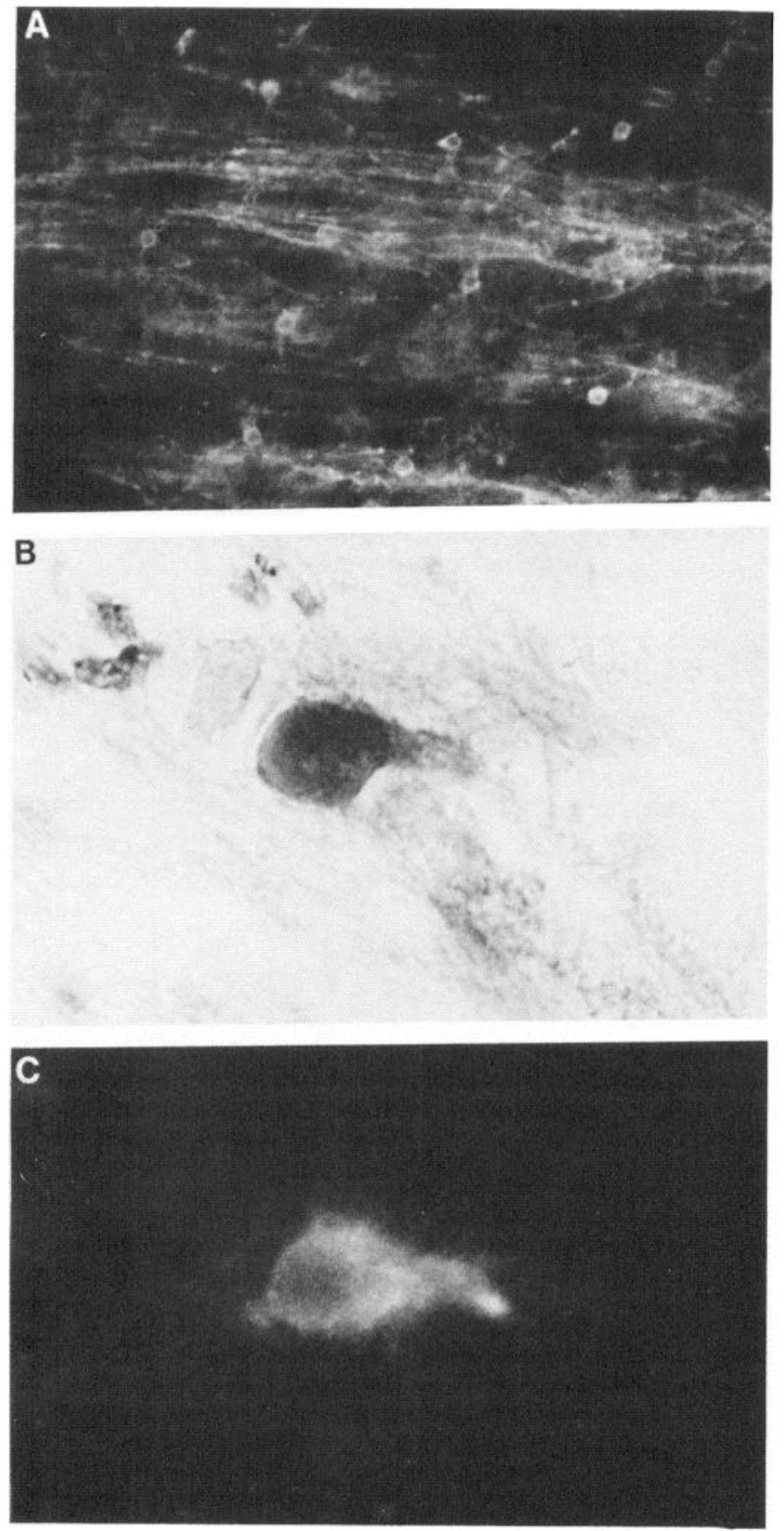

Figure 4. A, Anti-GC staining of myelin sheaths and oligodendrocytes within the lateral white matter at P10. $\times 198 . B$ and $C$, High-power views of a double-labeled section showing a cell stained with both $(B)$ anti-CA (PAP) and $(C)$ anti-GC (FITC) at P7. $\times 990$.

vimentin ${ }^{+}$or $\mathrm{GFAP}^{+}$processes that coursed through the SVZ to the ventricle appeared to run in between the small SVZ cells.

\section{Discussion}

We have used single- and double-labeling experiments to trace oligodendrocyte and astrocyte lineages in rat forebrain, employing a series of antibodies against markers that were expressed in overlapping intervals during development. Oligodendrocytes could be traced from $\mathrm{G}_{\mathrm{D} 3}+\mathrm{SVZ}$ cells into larger cells, which acquired CA, iron, and eventually GC. Astrocyte development from radial glia could also be followed.
We have attempted to describe cell lineages by examining a large series of images. This approach has limitations, but several lines of evidence support the scheme of oligodendrocyte lineage presented in this report. The use of AbR24 allowed us to follow the differentiation of SVZ cells as they increased in size and changed shape, appeared in subcortical white matter, and acquired other characteristics. The $\mathrm{G}_{\mathrm{D}^{3}}{ }^{+}$cells became $\mathrm{CA}^{+}$as large, round cells, seen in the SVZ and overlying white matter. CA labeling could then be followed through stages of process formation into small, interfascicular oligodendroglia (also see LeVine and Goldman, 1988a). Large, round cells and processbearing cells, identical in form and location to the $\mathrm{G}_{\mathrm{D}_{3}}{ }^{+} / \mathrm{CA}^{+}$ cells, were also positive with an iron stain, DAB-modified Prussian blue, that binds to oligodendrocytes (Francois et al., 1981; Hill and Switzer, 1984). Ultrastructural studies of $\mathrm{G}_{\mathrm{D} 3}{ }^{+}$cells in the developing white matter revealed membranous staining of cells with characteristics of immature and differentiating oligodendrocytes, supporting inferences from the labeling studies at the light microscopic level. Finally, cells labeled with the markers described above had shapes different from those cells containing vimentin and GFAP. Double-label experiments with intermediate filament antibodies and $G_{D 3}$ failed to show any double-labeled cells. This does not seem to result from methodological problems, since radial glia in rat spinal cord bound both R24 and anti-vimentin antibodies (Hirano and Goldman, 1986). This double labeling in cord was detected using immunofluorescence or immunofluorescence combined with peroxidase labeling. We have also examined cell suspensions from newborn rat forebrain and found $\mathrm{G}_{\mathrm{D} 3}{ }^{+}$cells (Goldman et al., 1986), but these cells do not also bind anti-vimentin or GFAP antibodies (unpublished observations). The small SVZ cells did not appear to be vimentin ${ }^{+}$or $\mathrm{GFAP}^{+}$. In fact, filament containing processes fell in between the $\mathrm{G}_{\mathrm{D} 3}{ }^{+}$or $\mathrm{G}_{\mathrm{D} 3}{ }^{+} / \mathrm{CA}^{+}$cells in the germinal zone. The high cellular density in this region may account for the conclusions in a previous report that SVZ cells contain vimentin (Schnitzer et al., 1981).

Oligodendrocytes in forebrain thus arise directly from SVZ cells. Early stages of differentiation occur in the SVZ itself, in that both large, round cells and process-bearing cells were observed therein. Early stages of oligodendrocyte development do not, therefore, require that the cells reside in white matter, where they would lie among axons. This lack of requirement for direct axonal contact seems analogous to phenomena in primary cultures, in which acquisition of such oligodendrocyte characteristics as GC and myelin basic protein (MBP) expression takes place in the absence of neurons (Labourdette et al., 1979; Raff et al., 1979; Abney et al., 1981; Goldman et al., 1986). Our observations also indicate that the SVZ contains a heterogeneous population since it includes both immature neuroectodermal cells and cells that have begun to differentiate along an oligodendrocytic pathway.

Oligodendrocytic characteristics appear to be acquired asynchronously. CA and the presence of iron arise very early. The prenatal appearance of CA is in agreement with a biochemical study by Sapirstein (1983). GC staining is not evident until cells develop thin processes, some attached to a myelin sheath, and is seen first in oligodendrocytes in lateral white matter, not in the cingulum. The acquisition of MBP, detected by immunocytochemistry, also appears late, like GC (LeVine and Goldman, 1988a).

We conclude that astrocytes in subcortical white matter and in gray matter are derived from radial glia, supporting previous 

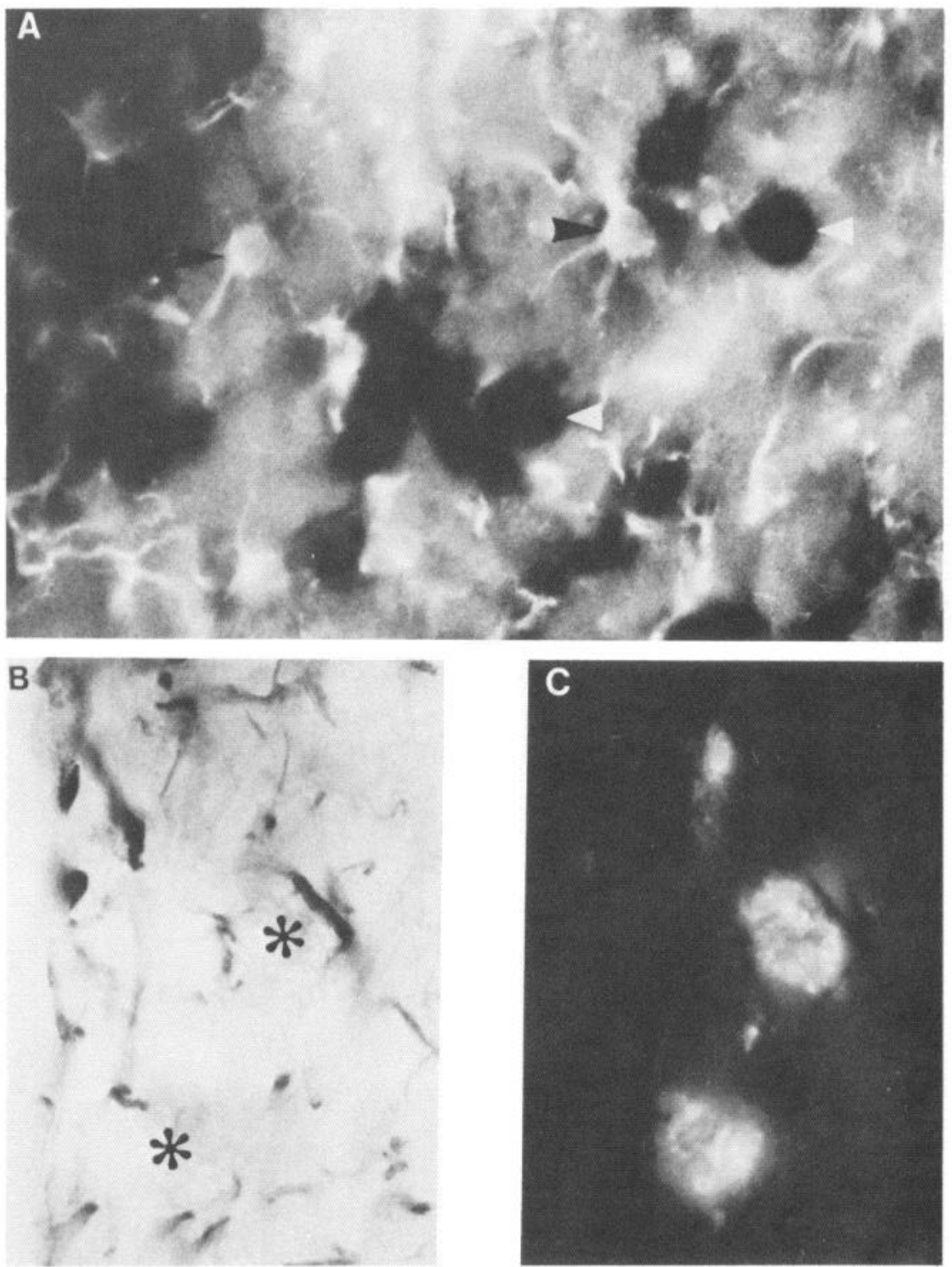

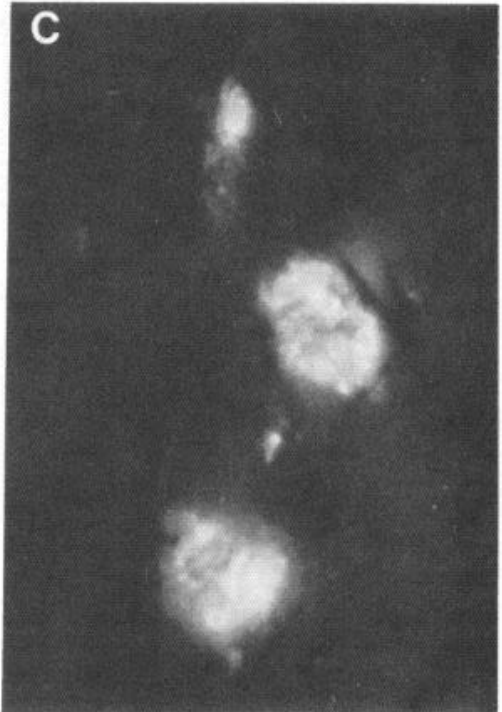

Figure 5. $A$, Double-labeled section with anti- $\mathrm{G}_{\mathrm{D} 3}$ (PAP, white arrowheads) and anti-GFAP (FITC, black arrowheads) just medial to the lateral ventricle (P4). Photomicroscopy was adjusted so both PAP and fluorescent products are visible in the same exposure. There is no concordance of staining. $\times 540$. Double-labeled section with $(B)$ anti-vimentin (PAP) and $(C)$ anti$\mathrm{G}_{\mathrm{D} 3}(\mathrm{Rh})(\mathrm{E} 20)$ is also shown. The $\mathrm{G}_{\mathrm{D} 3}{ }^{+}$ cells $(*)$ lie against the vimentin ${ }^{+}$processes, but there is no concordance of staining. $\times 990$. conclusions (Choi and Lapham, 1978; Schmechel and Rakic, 1979; Levitt and Rakic, 1980; Dahl et al., 1981; Schnitzer et al., 1981; Bovolenta et al., 1984). Double-label experiments showed that GFAP was first detected in processes that also contained vimentin. The earliest detectable GFAP labeling was noted midline between lateral ventricles and in midline subpial locations, at the base of the central sulcus, with appearance in the cingulum and lateral white matter at later times, consistent with the observations of Schnitzer et al. (1981). Transitions in forms from radial glial elements to process-bearing morphologies started in late embryonic life and continued through early postnatal life. The density of $\mathrm{GFAP}^{+} /$vimentin $^{+}$processes in the cingulum at $\mathrm{P} 7$ was remarkably high but diminished thereafter. Dense meshworks of astrocyte processes have been noted at similar postnatal periods in rodent cerebellar white matter and in optic nerve by Bovolenta et al. $(1984,1987)$. The changes in density may be due to several factors, including changes in process morphologies, from long, thick tortuous ones to shorter, straighter ones, or an increase in white matter volume at myelination.
There are limitations to studies that rely on cell markers to construct lineage relationships. These limitations allow for possible exceptions to the developmental scheme we propose. For example, we cannot rule out the generation of some astrocytes directly from SVZ cells rather than passing through an intermediate radial glial form. If such cells were to cease $G_{D 3}$ expression before the presence of vimentin or GFAP could be detected by immunocytochemistry, we would not have been able to discover any relationship between the 2 populations. If one can draw a parallel between forebrain and optic nerve gliogenesis, one could argue that astrocytes arising from a common progenitor cell in optic nerve, the Type II, A2B5 ${ }^{+}$astrocytes, could come directly from A2B5+ SVZ cells, without a radial intermediate. In optic nerve, such astrocytes arise later than those with the Type I, A2B5- phenotype (Miller et al., 1985). It was difficult with the methodology used here, however, to use A2B5 to trace glial development postnatally in situ, as have Miller et al. (1985) in optic nerve. Thus, our observations do not necessarily argue against 2 distinct lineages for astrocytes in forebrain. 
Figure 6. Anti- $\mathrm{G}_{\mathrm{D} 3}$ localization at the ultrastructural level in cingulum and subcortical white matter (PAP). Labeling is confined to the plasma membrane. $A$, An immature cell with a large nuclear to cytoplasmic ratio (P4). $\times 18,000$. $B$, A cell with a nuclear to cytoplasmic ratio less than that observed in cell $A$. There is peripheral chromatin clumping and the processes appear more developed. (P10) $\times 14,000$. $C$, A labeled process filled with microtubules. A Golgi apparatus is also visible (top). (P4) $\times 27,500$.

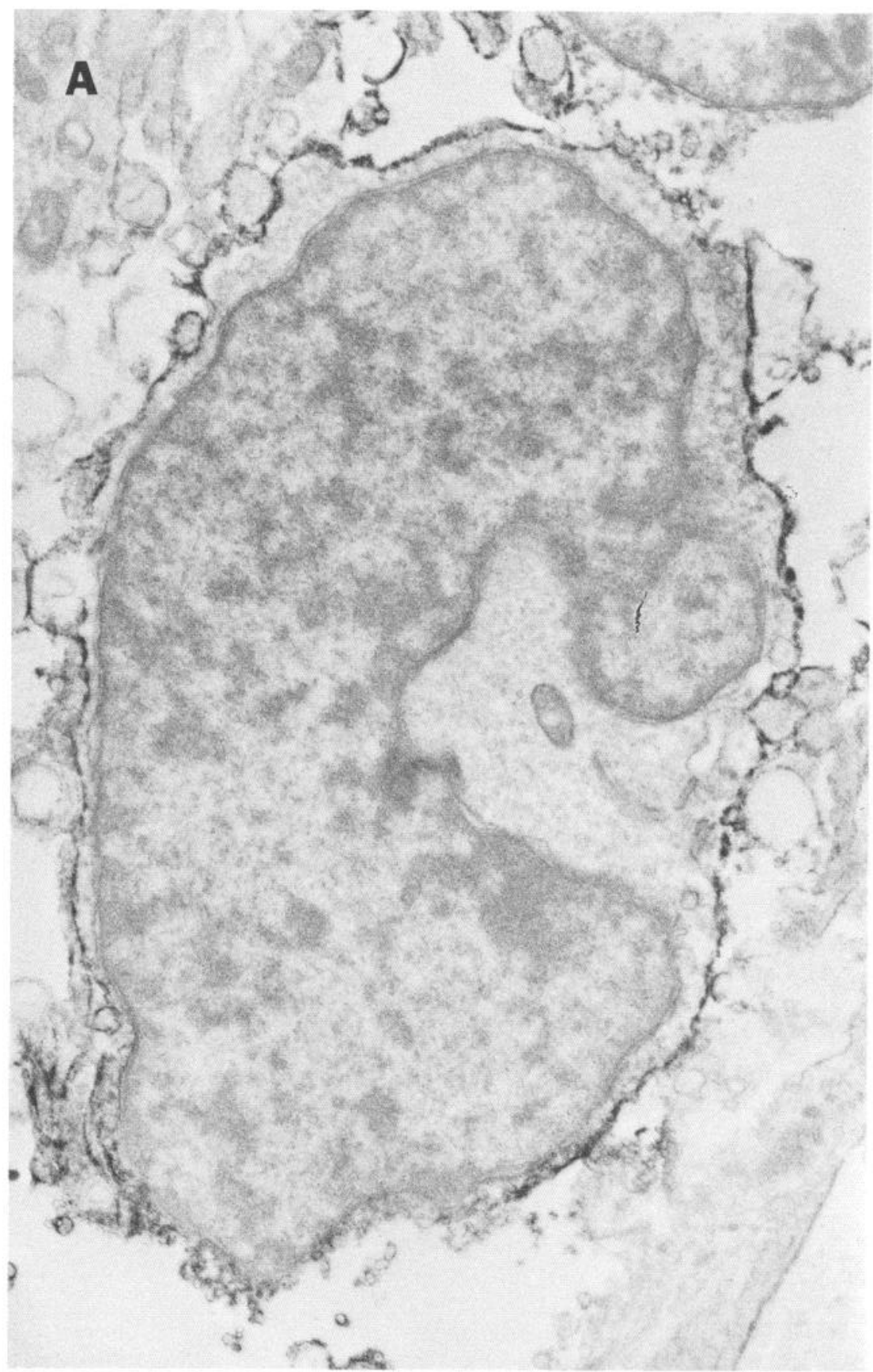

The A2B5+ oligodendrocyte precursors in optic nerve have different properties from $\mathrm{G}_{\mathrm{D} 3}+\mathrm{SVZ}$ cells in forebrain. For example, we could not detect the filament protein, vimentin, in $\mathrm{SVZ}$ cells that became forebrain oligodendrocytes, while A2 $\mathrm{B}^{+}$ precursors in optic nerve are vimentin ${ }^{+}$. One possible explanation for this difference is that the SVZ cells in forebrain are at an earlier stage of development than are the OA progenitor cells of optic nerve. A major anatomic difference between forebrain and optic nerve is that there is a large SVZ in the former at the time of oligodendrocyte development, while no SVZ resides in optic nerve at that point, although oligodendrocyte precursors in optic nerve do come originally from germinal zone cells, either those present at an earlier time or those that may migrate into the nerve. In this respect, optic nerve is more similar to spinal cord. Our recent observations in spinal cord indicate that radial glia are $\mathrm{G}_{\mathrm{D} 3}{ }^{+} / \mathrm{A} 2 \mathrm{~B} 5^{+} /$vimentin ${ }^{+}$. A subpopulation of these radial cells will express $\mathrm{CA}$ and become oligodendrocytes (Hirano and Goldman, 1986, 1988).

In primary cultures from newborn rat forebrain, $\mathrm{G}_{\mathrm{D} 3}{ }^{+}$cells are also A2B5+. These cells acquire GFAP reactivity before they stop expressing $\mathrm{G}_{\mathrm{D} 3}$ (Goldman et al., 1986). Developmental fates in vitro may not accurately reflect lineages in vivo, however. Indeed, the fact that $\mathrm{G}_{\mathrm{D} 3}+\mathrm{SVZ}$ cells can be followed into oligodendrocytes but not directly into astrocytes in vivo, yet most of the $\mathrm{G}_{\mathrm{D} 3}{ }^{+}$cells in vitro become astrocytic in the presence of fetal calf serum, strongly suggests that the culture conditions 


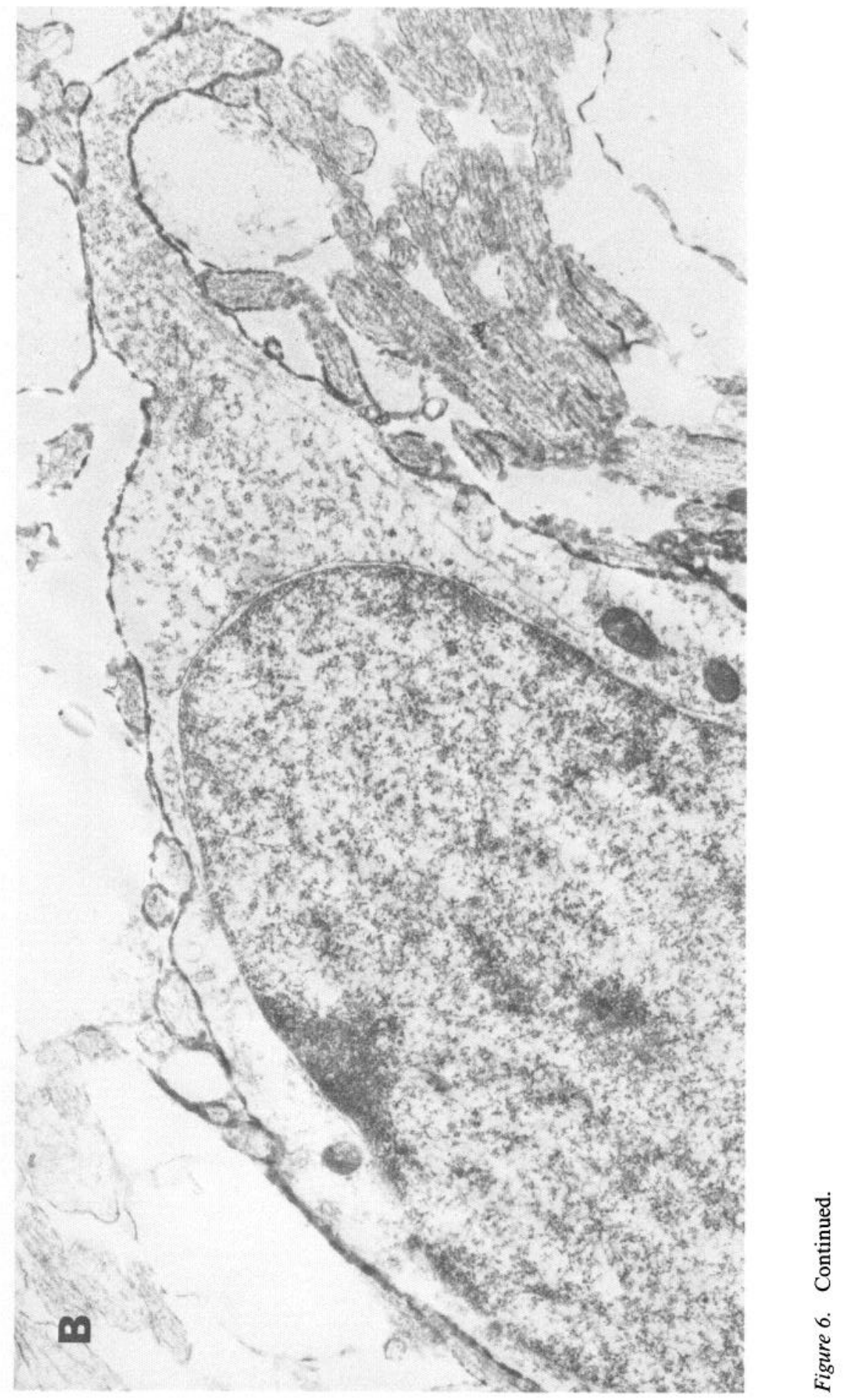




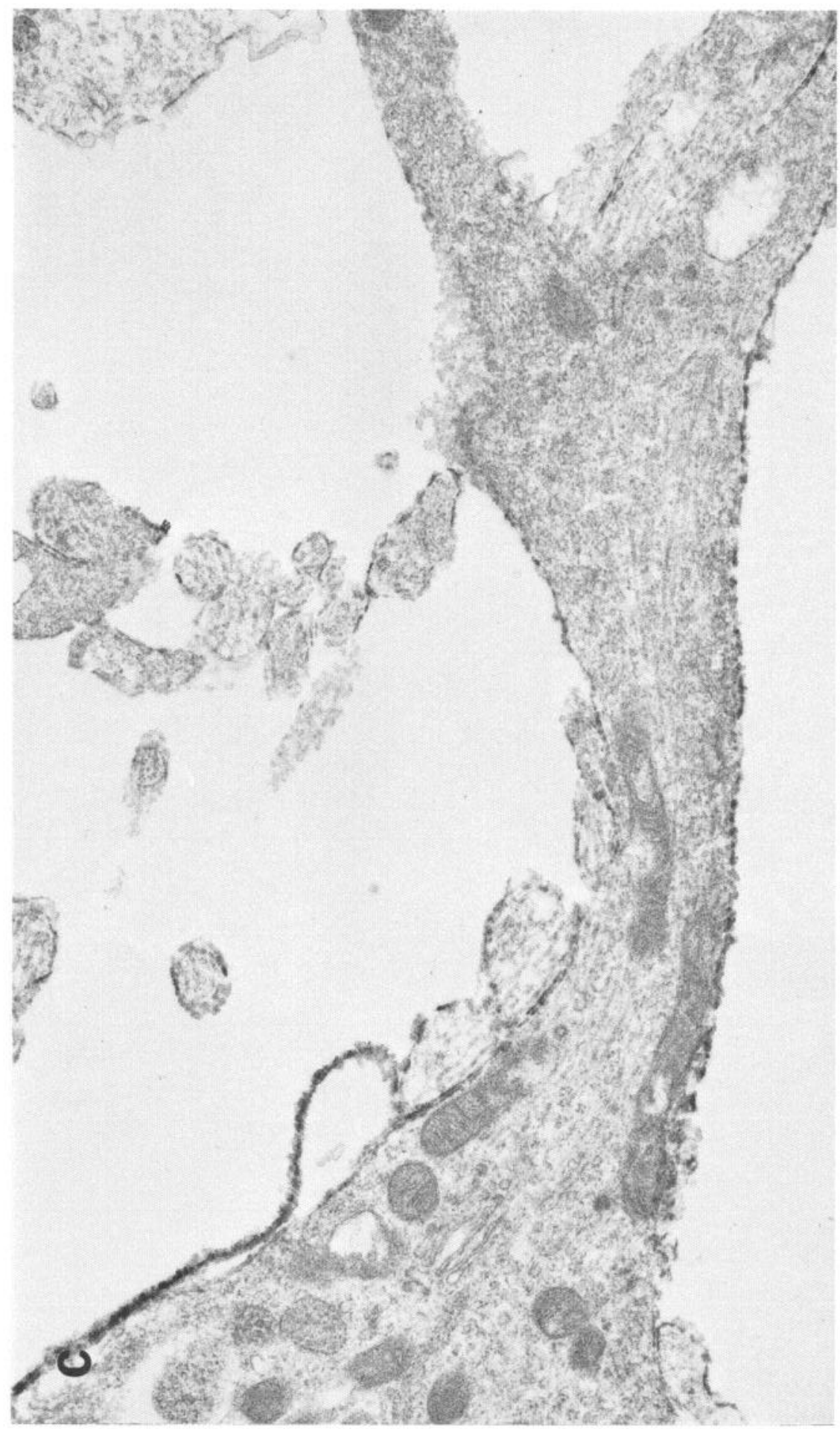



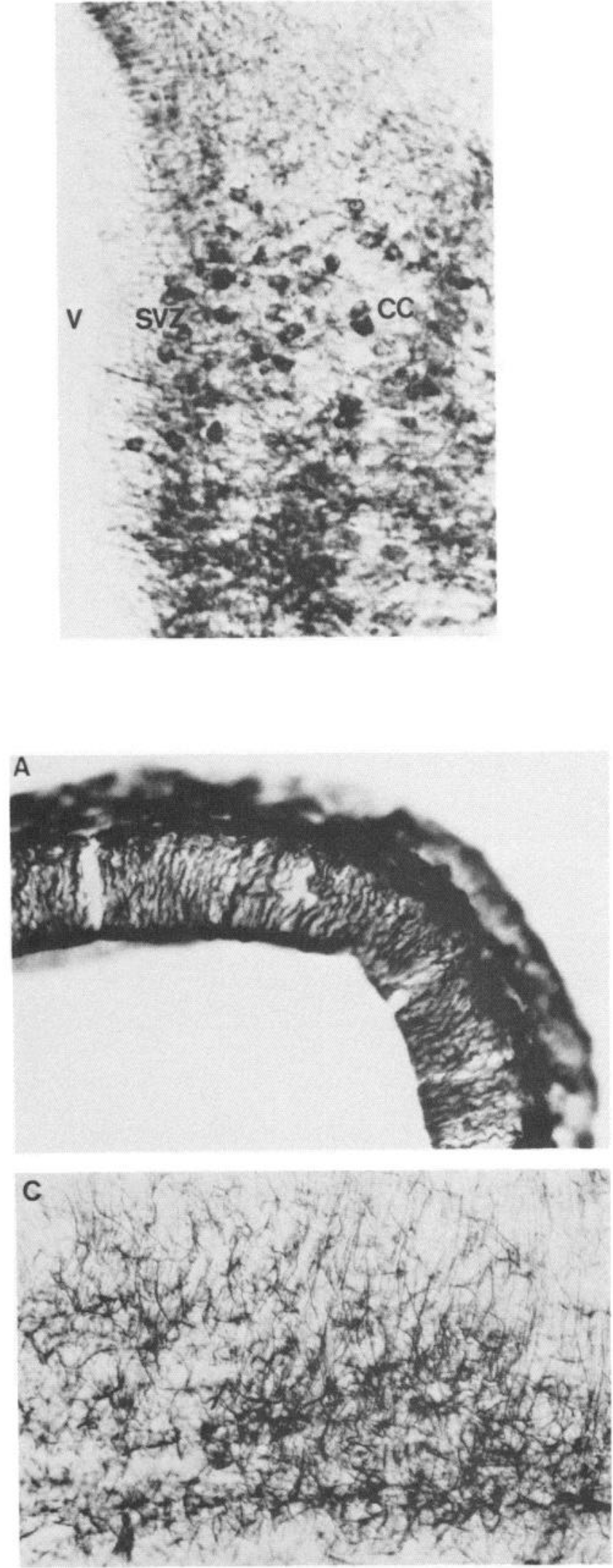

uncover developmental potential but do not promote fully normal lineage development.

We also cannot rule out the possible genesis of some forebrain oligodendrocytes from radial glial elements. It is conceivable, however, that in other parts of the CNS, oligodendrocyte derivation from radial cells may take place, as has been suggested in spinal cord (Choi and Kim, 1984; Hirano and Goldman, 1986, 1988).

A consideration of the literature brings up the question of whether some of the $\mathrm{G}_{\mathrm{D} 3}{ }^{+} / \mathrm{CA}^{+} /$iron + cells could be developing into microglia. Several studies have described large, round cells within the cingulum, termed them "ameboid microglia," and concluded that they represent precursors of microglia (Ling, 1981). This conclusion has been based on several observations. Various stains have been used to define these cells: silver carbonate, which stains both the large, round cells and resting microglia (Stensaas and Reichert, 1971; Ling, 1976), 5'-nucleo-

Figure 7. A2B5 staining showing large round cells admixed with axons and smaller cells of the SVZ (E20) $\times 216$. By early postnatal life, the axonal staining made it difficult to pick out individually labeled large, round cells.
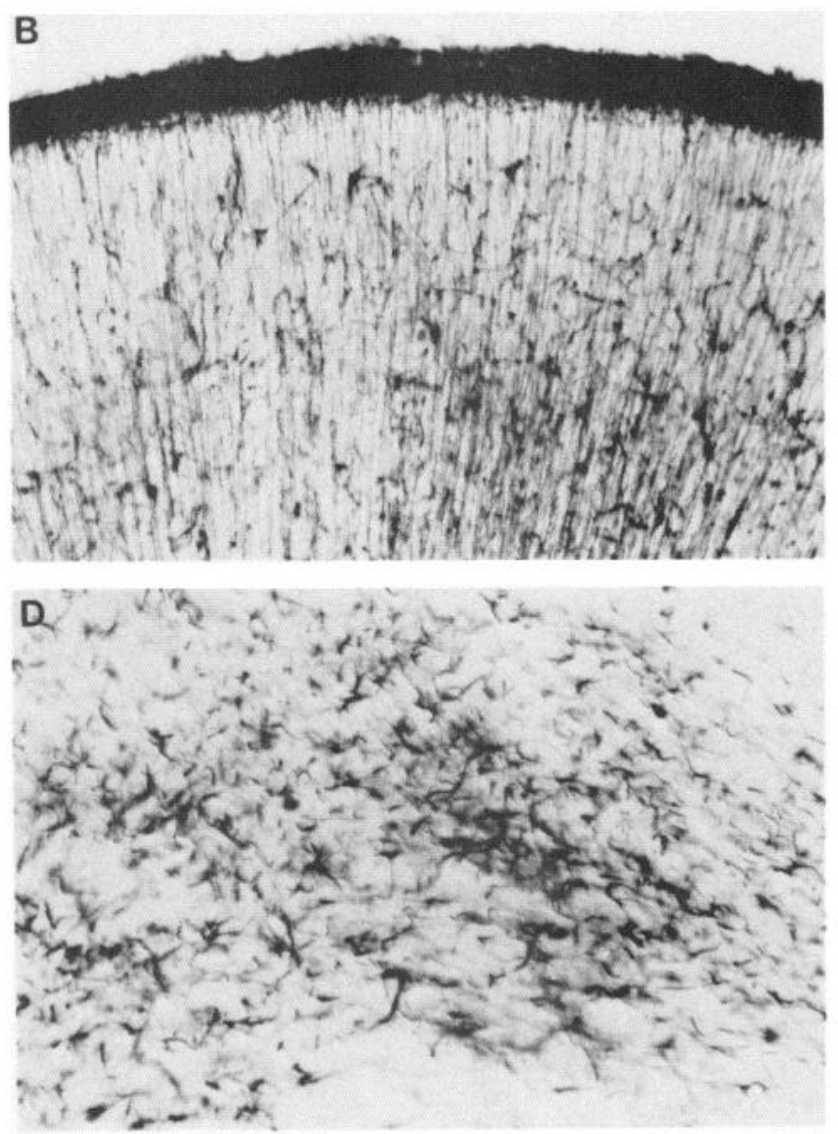

Figure 8. Anti-vimentin staining of $(A)$ E15 cortex, $(B)$ P0 cortex, $(C)$ P8 cingulum, and $(D)$ P16 cingulum. At E15 the radial glia span the thin width of the cortex. $\times 198$. At P0 some radial glia have detached from the pial surface and are condensing, while many remain elongated and attached. $\times 99$. At P8 many of the radial glia are converging on the cingulum, forming a tangled mesh, while other radial glial processes remain. $\times 198$. At P16 no radial processes are observed. The vimentin ${ }^{+}$cells have almost completely condensed, taking on the characteristic shape of astrocytes. $\times 198$. 

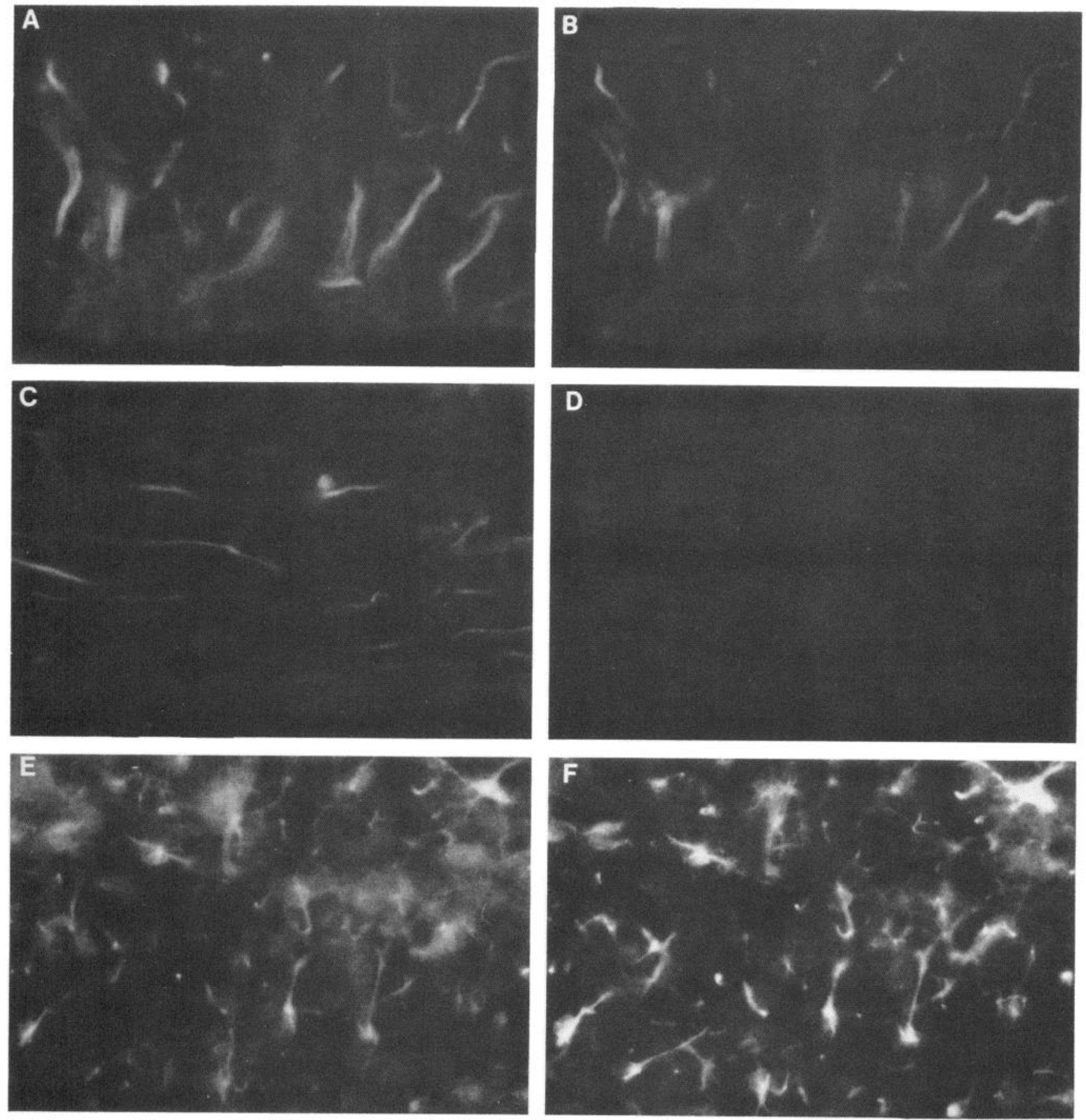

Figure 9. Double-labeled sections for vimentin ( Rh, $A, C$, and $E$ ) and GFAP (FITC, $B, D$, and $F$ ) showing the region midline between the ventricles at $\mathrm{P} 0(A$ and $B, \times 990)$ and the cingulum at $\mathrm{P} 0(C$ and $D, \times 990)$ and $\mathrm{P} 7(E$ and $F, \times 396)$. At $\mathrm{P} 0$ only the vimentin ${ }^{+}$radial glia midline between the ventricles are double labeled with anti-GFAP. At $7 \mathrm{~d}$ of age, the vimentin ${ }^{+}$cells throughout the brain are also GFAP ${ }^{+}$.

tidase (Kaur et al., 1984), aryl sulfatase (Ling, 1977), ATPase (Ling, 1977; Ferrer and Sarmiento, 1980), NADH dehydrogenase (Ferrer and Sarmiento, 1980), acid phosphatase (Ling, 1977), and nonspecific esterase (Valentino and Jones, 1981; Ling et al., 1982). All of the enzymes, save the last, have been found in oligodendrocytes (Friede, 1961; Vercelli-Retta et al., 1976; Kreutzberg et al., 1978; Abe et al., 1979; Zimmerman and Cammer, 1982; Cammer, 1984). None of the stains, save the $5^{\prime}-$ nucleotidase (Kreutzberg et al., 1978) and silver carbonate (Ling, 1976) has been localized to resting microglia. Silver carbonate also labels SVZ cells, however (Ling, 1976), "glioblasts" (Ling,
1976), oligodendrocytes (Dolman, 1985), and occasionally pericytes and astrocytes (Dolman, 1985). The anti-CA antibody used in this study does not bind to resting microglia in tissue sections (LeVine and Goldman, unpublished observations). The enzyme nucleoside diphosphatase (NDPase) has been localized to large, round cells and also to resting microglia (Murabe and Sano, 1982). Murabe and Sano (1982) also described the presence of thiamine pyrophosphatase in resting microglia, but not in the large, round cells. Thus, a large number of studies with enzyme markers have not conclusively demonstrated a developmental relationship between the large, round cells in the sub- 
cortical white matter and resting microglia. Furthermore, Boya et al. (1979) have disputed the relationship between ameboid microglia and resting microglial cells on the basis of acid phosphatase staining, arguing that resting microglia are derived from meninges and vessels.

A recent study (Sueyoshi et al., 1986) quantitated ameboid microglia, defined with macrophage markers, in developing rat brain and concluded that they were first seen about $E 15$, reached a maximal number by E18, and thereafter declined. The large, round cells we observe in the cingulum clearly reach a maximal number well after birth and remain for some time.

Thus, our study supports an oligodendrocyte lineage directly from SVZ cells in forebrain and a separate lineage for at least a large population of astrocytes from radial glia.

\section{References}

Abe, T., T. Miyatake, W. T. Norton, and K. Suzuki (1979) Activities of glycolipid hydrolases in neurons and astroglia from rat and calf brains and in oligodendroglia from calf brain. Brain Res. 161: 179182.

Abney, E. R., P. P. Barlett, and M. C. Raff (1981) Astrocytes, cpendymal cells, and oligodendrocytes develop on schedule in dissociated cell cultures of embryonic rat brain. Dev. Biol. 83: 301-310.

Bovolenta, P., R. K. H. Liem, and C. A. Mason (1984) Development of cerebellar astroglia: Transitions in form and cytoskeletal content. Dev. Biol. 102: 248-259.

Bovolenta, P., R. K. H. Liem, and C. A. Mason (1987) Glial filament protein expression in astroglia in the mouse visual pathway. Dev. Brain Res. 33: 113-126.

Boya, J., J. Calvo, and A. Prado (1979) The origin of microglial cells. J. Anat. 129: 177-186.

Cammer, W. (1984) Carbonic anhydrase in oligodendrocytes and myelin in the central nervous system. Ann. NY Acad. Sci. 429: 494497.

Cammer, W., T. Fredman, A. L. Rose, and W. T. Norton (1976) Brain carbonic anhydrase: Activity in isolated myelin and the effect of hexachlorophene. J. Neurochem. 27: 165-171.

Cammer, W., R. Sacchi, S. Kahn, and V. Sapirstein (1985) Oligodendroglial structures and distribution shown by carbonic anhydrase immunostaining in the spinal cords of developing normal and shiverer mice. J. Neurosci. Res. 14: 303-316.

Chiu, F.-C., and J. E. Goldman (1984) Synthesis and turnover of cytoskeletal proteins in cultured astrocytes. J. Neurochem. 42: 166174.

Choi, B. H., and R. C. Kim (1984) Expression of glial fibrillary acidic protein in immature oligodendroglia. Science 223: 407-409.

Choi, B. H., and L. W. Lapham (1978) Radial glia in the human fetal cerebrum: A combined Golgi, immunofluorescence and electron microscope study. Brain Res. 148: 295-311.

Dahl, D., D. C. Rueger, and A. Bignami (1981) Vimentin, the 57,000 molecular weight protein of fibroblast filaments, is the major cytoskeletal component of immature glia. Eur. J. Cell Biol. 24: 191-196.

Dolman, C. L. (1985) Microglia. In Textbook of Neuropathology, R. L. Davis and D. M. Robertson, eds., pp. 117-137, Williams \& Wilkins, Baltimore.

Ferrer, I., and J. Sarmiento (1980) Nascent microglia in the developing brain. Acta Neuropathol. (Berl.) 50: 61-67.

Francois, C., J. Nguyen-Legros, and G. Percheron (1981) Topographical and cytological localization of iron in rat and monkey brains. Brain Res. 215: 317-322.

Fredman, P., J. L. Magnani, M. Nirenberg, and V. Ginsburg (1984) Monoclonal antibody A2B5 reacts with many gangliosides in neuronal tissue. Arch. Biochem. Biophys. 233: 661-666.

Friede, R. (1961) A histochemical study of DPN-diaphorase in human white matter with some notes on myelination. J. Neurochem. 8: 1730.

Ghandour, M. S., O. K. Langley, G. Vincendon, and G. Gombos (1979) Double labeling immunohistochemical technique provides evidence of the specificity of glial cell markers. J. Histochem. Cytochem. 27: 1634-1637.
Ghandour, M. S., O. K. Langley, G. Vincendon, G. Gombos, D. Filippi, N. Limozin, C. Dalmasso, and G. Laurent (1980) Immunochemical and immunohistochemical study of carbonic anhydrase II in adult rat cerebellum: A marker for oligodendrocytes. Neuroscience 5: 559571 .

Goldman, J. E., M. Hirano, R. K. Yu, and T. N. Seyfried (1984) $G_{D 3}$ ganglioside is a glycolipid characteristic of immature neuroectodermal cells. J. Neuroimmunol. 7: 179-192.

Goldman, J. E., S. S. Geier, and M. Hirano (1986) Differentiation of astrocytes and oligodendrocytes from germinal matrix cells in primary culture. J. Neurosci. 6: 52-60.

Hill, J. M., and R. C. Switzer III (1984) The regional distribution and cellular localization of iron in the rat brain. Neuroscience 11: 595603.

Hirano, M., and J. E. Goldman (1986) An immunohistochemical study of rat spinal cord gliogenesis. Trans. Am. Soc. Neurochem. (abstr.) 17: 319 .

Hirano, M., and J. E. Goldman (1988) Gliogenesis in rat spinal cord: Evidence for origin of astrocytes and oligodendrocytes from radial precursors. J. Neurosci. Res. (in press).

Imamoto, K., J. A. Paterson, and C. P. Leblond (1978) Radioautographic investigation of gliogenesis in the corpus callosum of young rats. I. Sequential changes in oligodendrocytes. J. Comp. Neurol. 180: $115-138$.

Kasai, N., and R. K. Yu (1983) The monoclonal antibody A2B5 is specific for ganglioside $\mathrm{G}_{\mathrm{Q} 1 \mathrm{c}}$. Brain Res. 277: 155-158.

Kasai, N., M. Naiki, and R. K. Yu (1984) Autoradiography of ganglioside antigens separated by high-performance thin-layer chromatography with their antibodies. J. Biochem. 96: 261-264.

Kaur, C., E. A. Ling, and W.C. Wong (1984) Cytochemical localisation of $5^{\prime}$-nucleotidase in amoeboid microglial cells in postnatal rats. $J$. Anat. 139: 1-7.

Kreutzberg, G. W., and K. D. Barron (1978) 5'-nucleotidase of microglial cells in the facial nucleus during axonal reaction. J. Neurocytol. 7: 601-610.

Kumpulainen, T., and L. K. Korhonen (1982) Immunohistochemical localization of carbonic anhydrase isoenzyme $\mathrm{C}$ in the central and peripheral nervous system of the mouse. J. Histochem. Cytochem. 30: 283-292.

Kumpulainen, T., and S. H. M. Nystrom (1981) Immunohistochemical localization of carbonic anhydrase isoenzyme $\mathrm{C}$ in human brain. Brain Res. 220: 220-225.

Kumpulainen, T., D. Dahl, L. K. Korhonen, and S. H. M. Nystrom (1983) Immunolabeling of carbonic anhydrase isoenzyme $C$ and glial fibrillary acidic protein in paraffin-embedded tissue sections of human brain and retina. J. Histochem. Cytochem. 31: 879-886.

Labourdette, G., G. Roussel, M. S. Ghandour, and J. L. Nussbaum (1979) Cultures from rat brain hemispheres enriched in oligodendrocyte-like cells. Brain Res. 179: 199-203.

Langley, O. K., M. S. Ghandour, G. Vincendon, and G. Gombos (1980) Carbonic anhydrase: An ultrastructural study in rat cerebellum. Histochem. J. 12: 473-483.

Lechago, J., N. C. J. Sun, and W. M. Weinstein (1979) Simultaneous visualization of two antigens in the same tissue section by combining immunoperoxidase with immunofluorescence techniques. J. Histochem. Cytochem. 27: 1221-1225.

LeVine, S. M., and J. E. Goldman (1988a) Spatial and temporal patterns of oligodendrocyte development in rat forebrain. J. Comp. Neurol. (in press).

LeVine, S. M., and J. E. Goldman (1988b) Ultrastructural characteristics of $\mathrm{G}_{\mathrm{D} 3}+$ immature glia in developing rat white matter. J. Comp. Neurol. (in press).

Levitt, P., and P. Rakic (1980) Immunoperoxidase localization of glial fibrillary acidic protein in radial glial cells and astrocytes of the developing rhesus monkey brain. J. Comp. Neurol. 193: 815-840.

Ling, E. A. (1976) Some aspects of amoeboid microglia in the corpus callosum and neighboring regions of neonatal rats. J. Anat. 121: 2945.

Ling, E. A. (1977) Light and electronmicroscopic demonstration of some lysosomal enzymes in the amoeboid microglia in neonatal rat brain. J. Anat. 123: 637-648.

Ling, E. A. (1981) The origin and nature of microglia. Adv. Cell. Neurobiol. 2: 33-82.

Ling, E. A., C. Kaur, and W. C. Wong (1982) Light and electronmicroscopic demonstration of non-specific esterase in amoeboid mi- 
croglial cells in the corpus callosum in postnatal rats: A cytochemical link to monocytes. J. Anat. 135: 385-394.

Miller, R. H., S. David, R. Patel, E. R. Abney, and M. C. Raff (1985) A quantitative immunohistochemical study of macroglia cell development in the rat optic nerve: In vivo evidence for two distinct astrocyte lineages. Dev. Biol. 111: 35-41.

Murabe, Y., and Y. Sano (1982) Morphological studics on ncuroglia. VI. Postnatal development of microglial cells. Cell Tissue Res. 225. $469-485$

Norton, W. T., M. Farooq, K. L. Fields, and C. S. Raine (1983) The long term culture of bulk-isolated bovine oligodendroglia from adult brain. Brain Res. 270: 295-310.

Paterson, J. A., A. Privat, E. A. Ling, and C. P. Leblond (1973) Investigation of glial cells in semithin sections. III. Transformation of subependymal cells into glial cells, as shown by radioautography after ${ }^{3} \mathrm{H}$-thymidine injection into the lateral ventricle of the brain of young rats. J. Comp. Neurol. 149: 83-102.

Pukel, C. S., K. O. Lloyd, L. R. Travassos, W. G. Dippold, H. F. Oettgen, and L. J. Old (1982) $\mathrm{G}_{\mathrm{D} 3}$, a prominent ganglioside of human melanoma. J. Exp. Med. 155: 1133-1147.

Raff, M. C., K. L. Ficlds, S.-I. Hakomori, R. Mirsky, R. M. Pruss, and J. Winter (1979) Cell-type-specific markers for distinguishing and studying neurons and the major classes of glial cells in culture. Brain Res. 174: 283-308.

Raff, M. C., B. P. Williams, and R. H. Miller (1984) The in vitro differentiation of a bipotential glial progenitor cell. EMBO J. 3: $1857-$ 1864.

Rosner, H., M. Al-Aqtum, and S. Henke-Fahle (1985) Developmental expression of $G_{03}$ and polysialogangliosides in embryonic chicken nervous tissue reacting with monoclonal antiganglioside antibodies. Dev. Brain Res. 18: 85-95.

Sapirstein, V. S. (1983) Carbonic anhydrase. In Handbook of Neurochemistry, A. Lajtha, ed., pp. 385-402, Plenum, New York.

Sapirstein, V., M. Trachtenberg, M. B. Lees, and O. Koul (1978) Regional developmental and fractional studies on myelin and other carbonic anhydrases in rat CNS. In Advances in Experimental Medicine and Biology: Myelin and Demyelination, J. Palo, ed., pp. 55-70, Plenum, New York.

Schmechel, D. E., and P. Rakic (1979) A Golgi study of radial glial cells in developing monkey telencephalon: Morphogenesis and transformation into astrocytes. Anat. Embryol. 156: 115-152.

Schnitzer, J., W. W. Franke, and M. Schachner (1981) Immunocytochemical demonstration of vimentin in astrocytes and ependymal cells of developing and adult mouse nervous system. J. Cell Biol. 90: 435-447.

Sharp, G., M. Osborn, and K. Weber (1982) Occurrence of two different intermediate filament proteins in the same filament in situ within a human glioma cell line. Exp. Cell Res. 141: 385-395.
Skoff, R. P. (1980) Neuroglia: A reevaluation of their origin and development. Pathol. Res. Pract. 168: 279-300.

Skoff, R., D. Price, and A. Stocks (1976a) Electron microscopic autoradiographic studies of gliogenesis in rat optic nerve. I. Cell proliferation. J. Comp. Neurol. 169: 291-312.

Skoff, R., D. Price, and A. Stocks (1976b) Electron microscopic autoradiographic studies of gliogenesis in rat optic nerve. II. Time of origin. J. Comp. Neurol. 169: 313-333.

Spicer, S., P. J. Stoward, and R. E. Tashian (1979) The immunohistolocalization of carbonic anhydrase in rodent tissues. J. Histochem. Cytochem. 27: 820-821.

Stensaas, L. J., and W. H. Reichert (1971) Round and ameboid microglial cells in the neonatal rabbit brain. Z. Zellforsch. 119: 147163.

Sternberger, L. A., and S. A. Joseph (1979) The unlabeled antibody method. Contrasting color staining of paired pituitary hormones without antibody removal. J. Histochem. Cytochem. 27: 1424-1429.

Sturrock, R. R. (1976) Light microscopic identification of immature glial cells in semithin sections of the developing mouse corpus callosum. J. Anat. 122: 521-537.

Sueyoshi, N., Y. Matsukado, K. Takahashi, and M. Naito (1986) Cytological characterization of ameboid microglia in the brain of rat fetuses. Xth International Congress of Neuropathology, p. 56 (abstr.).

Temple, S., and M. C. Rafl (1985) Differentiation of a bipotential glial progenitor cell in single cell microcultures. Nature 313: 223-225.

Valentino, K. L., and E. G. Jones (1981) Morphological and immunocytochemical identification of macrophages in the developing corpus callosum. Anat. Embryol. 163: 157-172.

Vaughn, J. (1969) An electron microscopic analysis of gliogenesis in rat optic nerves. Z. Zellforsch. 94: 293-324.

Vercelli-Retta, J., R. Silviera, F. Dejas, and D. Rodriguez (1976) Enzyme histochemistry of rat interfascicular oligodendroglia, with special reference to 5'-nucleotidase. Acta Anat. 96: 534-546.

Wood, P., and R. P. Bunge (1984) The biology of the oligodendrocyte. Adv. Neurochem. 5: 1-46.

Yandrasitz, J. R., S. A. Ernst, and L. Salganicoff (1976) The subcellular distribution of carbonic anhydrase in homogenates of perfused rat brain. J. Neurochem. 27: 707-715.

Zalc, B., M. Monge, P. Dupouey, J. J. Hauw, and N. A. Baumann (1981) Immunohistochemical localization of galactosyl and sulfogalactosyl ceramide in the brain of the 30-day-old mouse. Brain Res. 211:341354.

Zimmerman, T. R., and W. Cammer (1982) ATPase activities in myelin and oligodendrocytes isolated from the brains of developing rats and from bovine brain white matter. J. Neurosci. Res. 8: 73-81. 